
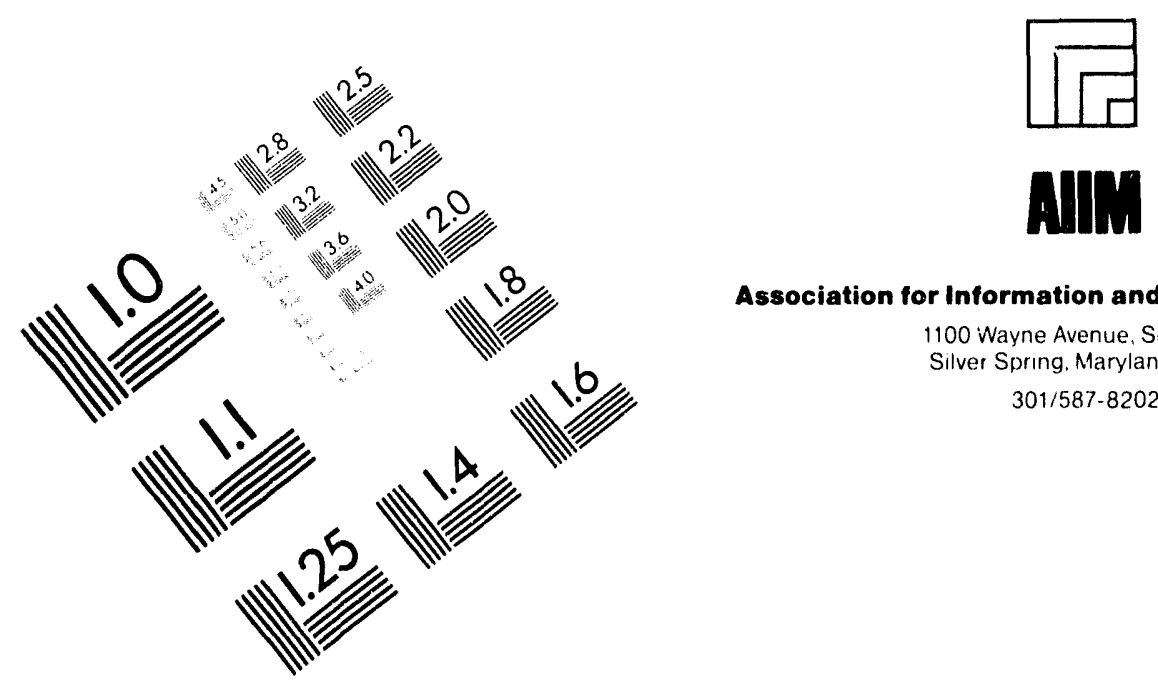

Association for Information and Image Management

1100 Wayne Avenue, Suite 1100

Silver Spring. Maryland 20910

301/587-8202

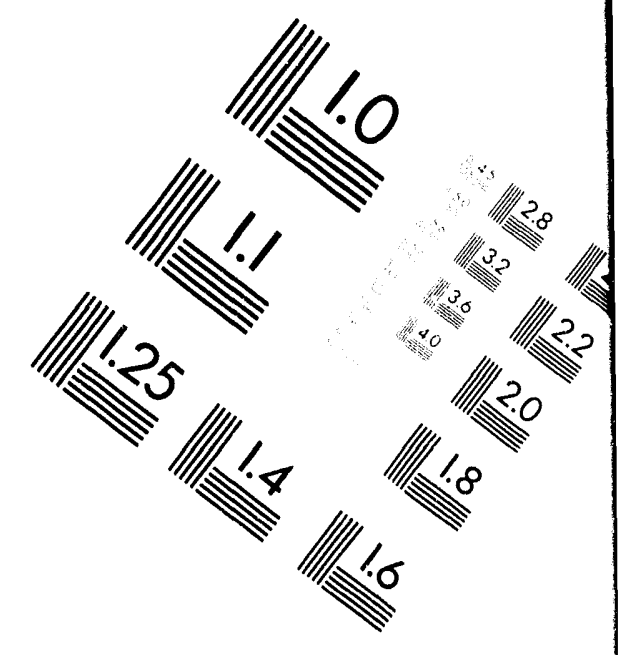

\title{
Centimeter
}

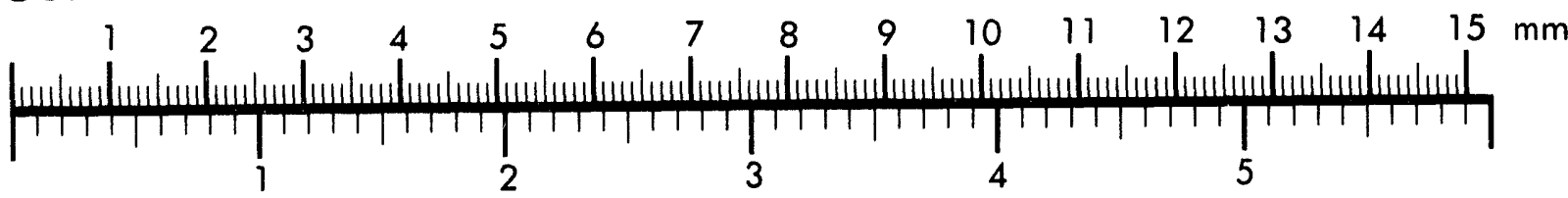

Inches
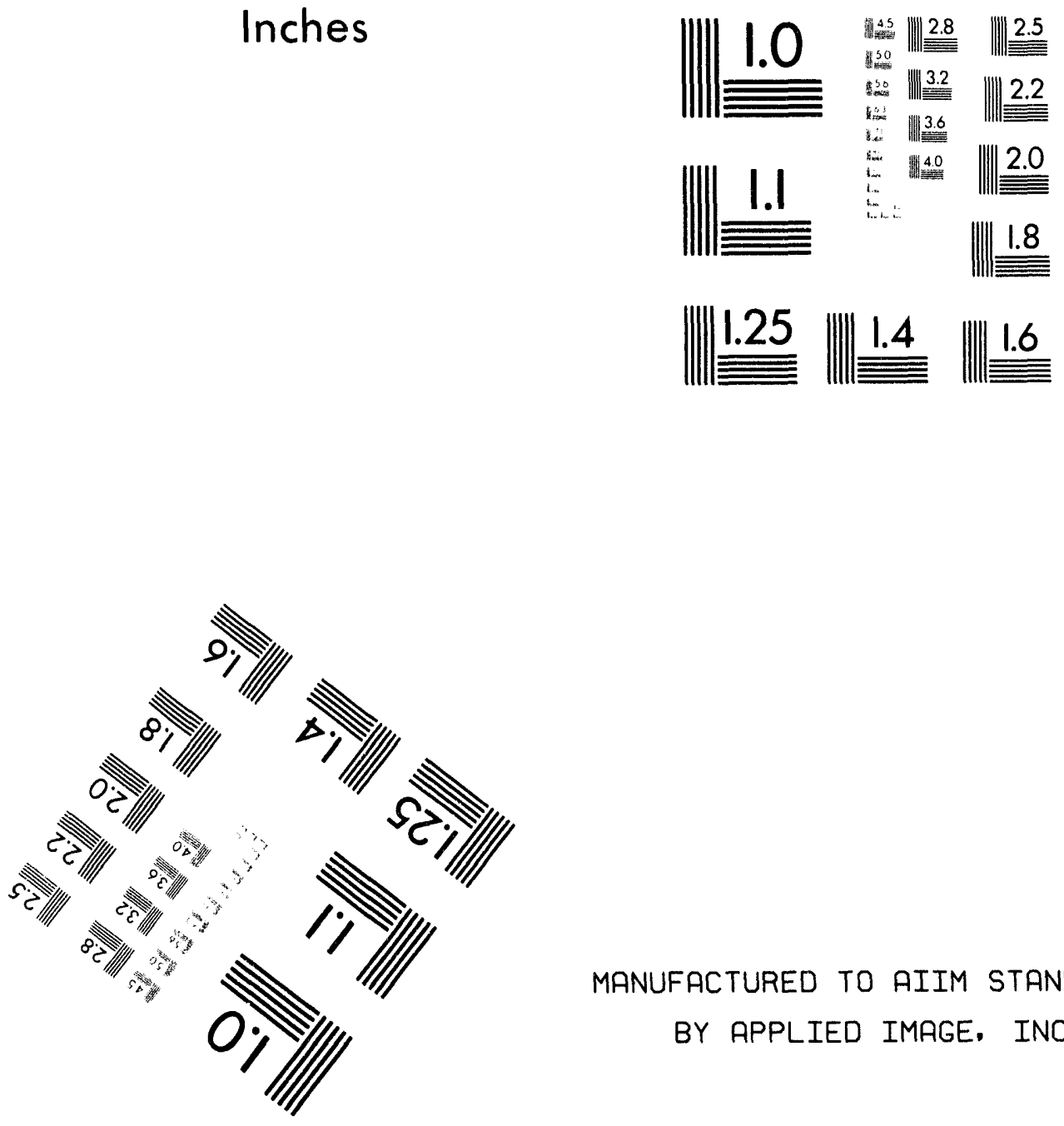

MANUFACTURED TO AIIM STANDARDS

BY APPLIED IMAGE. INC.

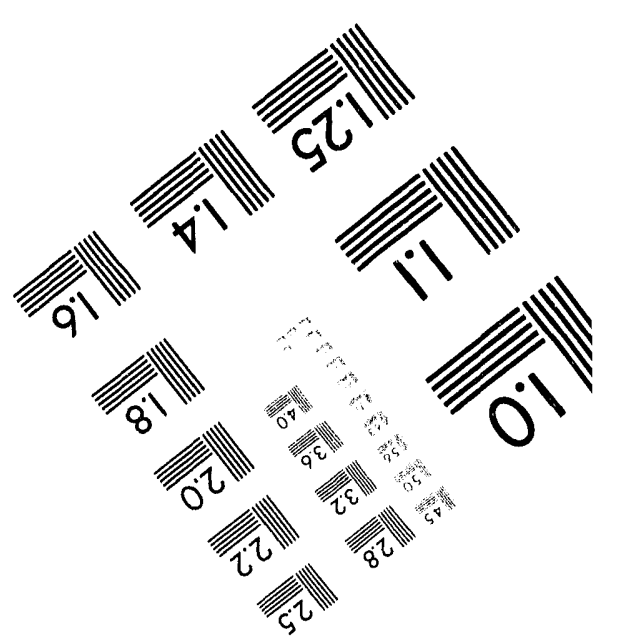



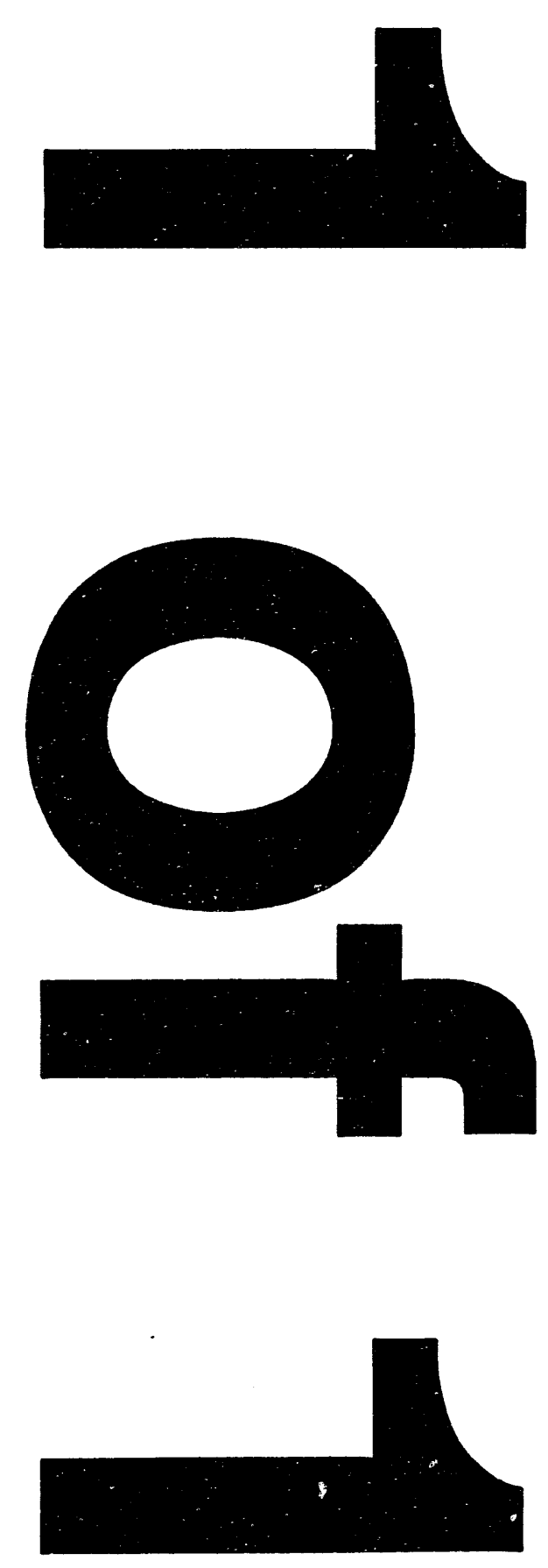


\section{AXIAL PISTON PUMP WEAR PLATES, DELTA-Q CORPORATION \\ (U)}

by

J. K. Campbell

Westinghouse Savannah River Company

Savannah River Site

Aiken, South Carolina 29803

M. Baker White

DOE Contract No. DE-AC09-89SR18035

This paper was prepared in connection with work done under the above contract number with the U.S.

Department of Energy. By acceptance of this paper, the publisher and/or recipient acknowledges the U.S. Government's right to retain a nonexclusive, royalty-free license in and to any copyright covering this paper, along with the right to reproduce and to authorize others to reproduce all or part of the copyrighted paper. 


\section{DISCLAIMER}

This report was prepared as an account of work sponsored by an agency of the United States Government. Neither the United States Government nor any agency theriof, nor any of their employees, makes any warranty, express or implied, or assumes any legal liability or responsibility for the accuracy, completeness, or usefulness of any information, apparatus, product, or process disclosed, or represents that its use would not infringe privately owned rights. Reference herein to any specific commercial product, process, or service by trade name, trademark, manufacturer, or otherwise does not necessarily constitute or imply its endorsement, recommendation, or favoring by the United States Government or any agency thereof. The views and opinions of authors expressed berein do not necessarily state or reflect those of the United. States - Government or any agency thereof.

This report has been reproduced directly from the best available copy.

Available to DOE and DOE contractors from the Office of Scientific and Technical Information, P. O. Box 62, Oak Ridge, TN 37831; prices available from (615) $576-8401$.

Available to the public from the National Technical Information Service, U. S. Deparment of Commerce, 5285 Port Royal Rd., Springfield, VA 22161 
VP Engineering

Delta-Q Corp.

639 South Old Belair Rd.

Grovetown, GA 30813

\section{Dear Sir:}

\section{Subject: AXIAL PISTON PUMP WEAR PLATES, DELTA-Q CORPORATION (U)}

\section{Summary and Recommendation}

The Savannah River Technical Center visually examined several axial piston pump wear plates from Delta-Q Corporation in an effort to determine the cause of the scratches. The investigation found the material and hardness to be approximately consistent with vendor specifications. The visual examination revealed gouges and tears on plates $1-4$, silicon and aluminum contamination on plates $2 \& 3$ and a heavy inclusion content in the base metal. The scratches were most likely attributable to either metal debris created by the protruding metal around the gouges and tears or the silicon and aluminum contamination. The heavy inclusion content may have contributed by providing sites for the gouges and tears to develop during fabrication. It is recommended that tighter controls be introduced during procurement to ensure cleaner, inclusion controlled, steel and controlling the silicon and aluminum contamination during process assembly of the pumps. Specific surface texture requirements may also be considered for final machining.

\section{Background}

Materials Technology Section (MTS) of Savannah River Technical Center (SRTC), received six axial piston pump wear plates from Delta-Q Corporation, Grovetown, GA to determine the cause of the scratches which had developed after performance testing. Four plates were representative of the various conditions of the plates after processing. The other two plates were representative of plates previously fabricated with an alternative surface hardening technique and were submitted for comparison. The scratches that developed after performance testing are believed to be attributed to contamination. (note: no performance tested plate was provided). MTS was requested to identify the contaminant, possible sources and recommend a process to reduce or eliminate its presence (1). In addition, MTS was requested to identify the contaminant which appeared on one axial piston pump shoe.

The axial piston pump wear plates were constructed of AISI 8620 alloy steel, ground to size, carburized and heat treated to vendor specifications. The six wear plates received by MTS were in the following condition:

Plate 1 Ground and carburized to 0.030 " depth with final removal of $0.005^{\prime \prime}$ from each side (as received condition) 
Gary Sutton

April 6, 1994

SRT-MTS-945052

Page 2 of 19

Plate 2 Plate 1 condition and subjected to a lapping operation using alumina oxide (medium grit) with oil (performed at Delta-Q facility)

Plate 3 Plate 2 condition and vibra slide detergent cleaned (performed at Delta-Q facility)

Plate 4 Plate 1 condition and subjected to muriatic acid etching (performed at Delta-Q facility)

Plate 5 Ground and "Nitrotec" surface hardened to 0.0010" 0.0015 " depth (as received condition)

Note: Nitrotec is a proprietary surface hardening treatment performed by a vendor.

Plate 6 Plate 5 condition and subjected to performance testing.

Results

The working surfaces of the six axial piston pump wear plates were visually examined using an scanning electron microscope (SEM) and the elemental analysis was conducted using energy dispersive X-ray spectroscopy (EDX). The elemental analysis for the plate material (plate 1) identified the presence of manganese $(1 \%)$, chromium $(0.5 \%)$, silicon $(<0.5 \%)$, nickel $(<0.5$ $\%)$, molybdenum ( $<0.5 \%)$ and the remainder iron. The carbon analysis performed on a Leco carbon analyzer indicated the carbon content was $0.276 \%$.This analysis is consistent with AISI 8620. Hardness measurements conducted with a Wilson Rockwell hardness tester, indirated the case hardness to be $55 \mathrm{HRC}$.

\section{PLATE 1}

The overall condition of the working surface showed machining marks covering the entire surface (Figure 1). The presence of gouges and tears and metal protrusion associated with these flaws was also observed (Figure 2). EDX analysis within the gouges revealed no evidence of foreign material or contamination.

A metallurgical analysis was conducted on the cross section indicated a martensitic microstructure, typical for the material and heat treatment. The microstructural analysis revealed a significantly high presence of nonmetallic inclusion known as stringers (Figure 3 ). The material was found to have an inclusion rating number of $5(\operatorname{Method} A)(2)$.

\section{PLATE 2}

The overall condition of the working surface showed a relatively smoother surface with no evidence of machining marks (Figure 4) as observed in plate 1. However, evidence of metal deformation (Figure 5) was observed. Evidence of gouging and contamination (Figure 6) also was present across the surface. EDX analysis of the particles appearing in Figure 6 identified the particles to contain silicon and aluminum. EDX analysis of other particles also revealed the presence of chlorine, sulfur, carbon, oxygen, sodium and calcium throughout the surface. These particles were confined in the surface (not embedded) and, in general, can be attributed to handling or shipping of the parts. Particles of this nature were observed to some degree on all plates. 
Gary Sutton

April 6, 1994

SRT-MTS-945052

Page 3 of 19

\section{PLATE 3}

The overall condition of the working surface showed a relatively smooth surface similar to that of plate 2 except for the presence of scratches. It was apparent that the vibra slide detergent cleaning operation had degraded the general surface condition and introduced scratches (Figure 7). Closer examination showed the presence of pre-existing gouges or flaws which had been deformed during the cleaning operation (Figure 8). Gouges which apparently were induced by the cleaning operation (Figure 9) were also observed. EDX analysis again found embedded particles to contain silicon and aluminum.

\section{PLATE 4}

The overall condition of the working surface was very similar to that of plate 1 , displaying machining marks over the entire surface (Figure 10). The surface showed the presence of iron particles (confirmed by EDX analysis) which appearing to be associated with the machining of the part (Figure 11). Gouges were also present (Figure 12).

\section{PLATE 5}

The overall condition of the working surface was very similar to that of plate 3 . The surface was relatively smooth with scratches (Figure 13).

\section{PLATE 6}

The general condition of the surface was obscured due to surface oxidation. However the presence of what appeared to be faint machining marks was observed (Figure 14).

\section{SHOE}

EDX analysis indicated the shoe was fabricated from a brass material with an approximate composition of $65 \%$ copper and $35 \%$ zinc. The contaminant found on the shoe surface (Figure 15) was identified as essentially iron.

\section{$\underline{\text { Discussion }}$}

The defects seen in plate 1 appear to have been induced during the machining operation. Such metal deformation could only be produced when the plate was subjected to harder materials such as cutting tools. The heavy inclusion content would offer likely sites for gouges to develop during machining due to hardness differences between the steel and non-metallics. Poor tool sharpness or excessive rate of metal removal could also contribute. Evidence of gouges and tears was observed, to some degree, on each of the plates 1-4. The silicon and aluminum particles found on the surfaces were likely introduced during the lapping or cleaning operations.

The scratches which developed on the wear plates after performance testing probably resulted from the metal debris associated with the metal protrusion in and around the gouges and tears. This debris could be harder than the parent material due to work hardening and would therefore inflict damage to the wear plate and the brass shoes. Silicon and aluminum particles also possess a high hardness and could also inflict damage.

\section{$\underline{\text { Recommendations }}$}

1. It is recommended that tighter controls be placed on the general cleanliness of the plate material during procurement. Specifically, stipulations could include requiring a secondary melting operation using either electro-slag remelting or vacuum arc remelting and a fine grain size. Consult ASTM A322, "Standard Specification for Steel Bars, 
Gary Sutton

April 6, 1994

SRT-MTS-945052

Page 4 of 19

Alloy, Standard Grades", Sections 5.1, "Materials and Manufacture" and Supplementary Requirements, Section S10, Grain Size (Fine).

2. It is recommended that the silicon and aluminum contamination be controlled. Thorough cleaning between processing steps should reduce the contamination.

3. Specific surface texture requirements should also be considered for final machining. Consult ANSI/ASME B46.1, "Surface Texture (Surface Roughness, Waviness, and Lay)".

\section{References}

1. Letter from Mr. Gary Sutton, Delta-Q Corporation to Dr. Jim Weaver, Augusta Technical Institute, Dated February 25, 1994

2. ASTM E45-87, "Standard Practice for Determining the Inclusion Content of Steel", 1990 Annual Book of ASTM Standards.

If I can be of further assistance on this subject, please feel free to call me at (803) 725-1318.

Sincerely,

mBam Qwht

M. Baker White

Bldg. 730-A

P. O. Box 616

Savannah River Technology Center

Aiken, SC 29808

Peer Review:

Technician Assistance:

T. M. Stefek

T. B. Curtis

S. A. Hatcher

cc:

G. J. Hooker, 770-A

T. L. Capeletti, 773-41A

R. L. Bickford, 730-A

N. C. Iyer, 773-A

D. T. Rankin, 773-A

A. P. Rangus, BTC

M. Hapstack, 723-9A

Group Copy
Retention: None

Subject Describers:

Pumps

Abrasion

Carbon Steels 
Gary Sutton

April 6, 1994

SRT-MTS-945052

Page 6 of 19

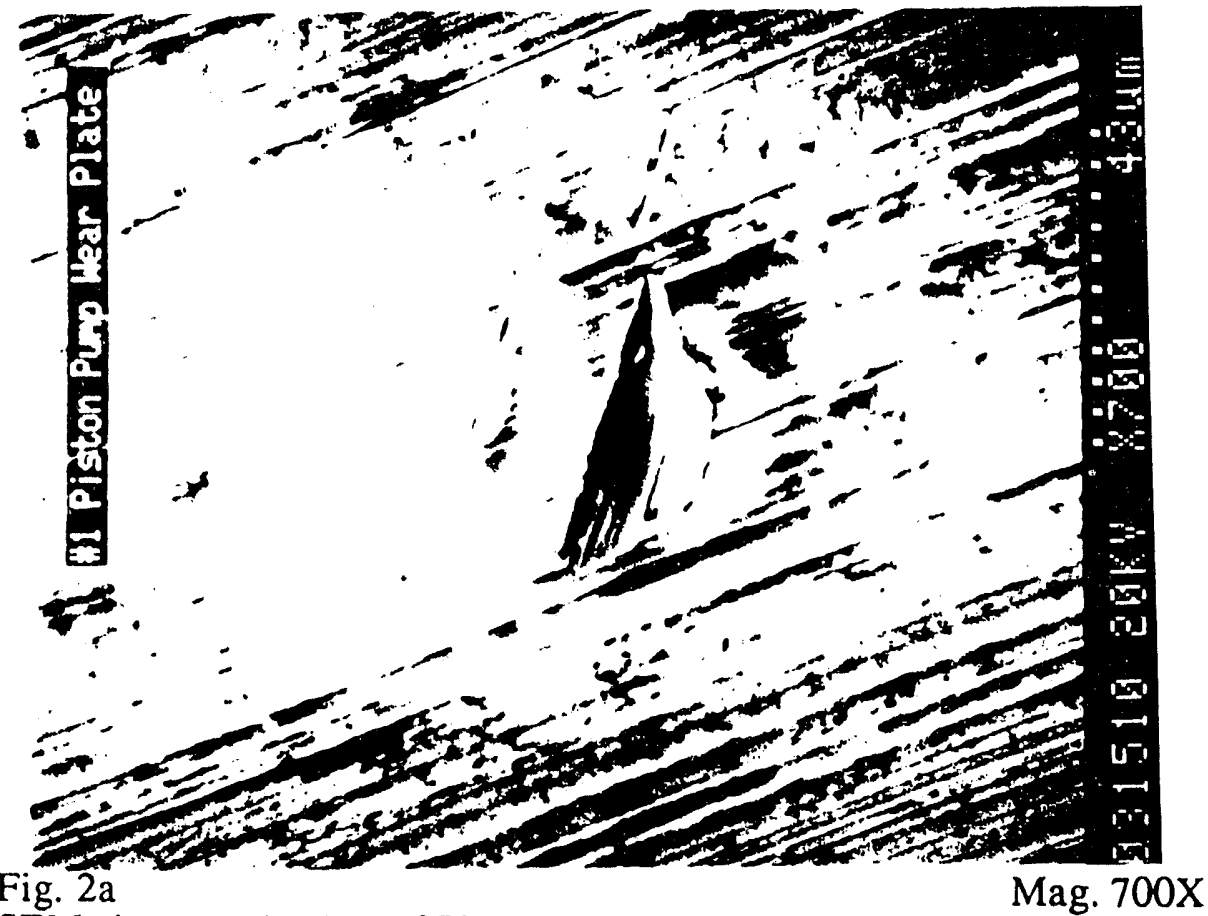

SEM photograph taken of Plate 1 showing a tear across the machining marks. EDX analysis within the tear revealed no evidence of foreign material or contamination.

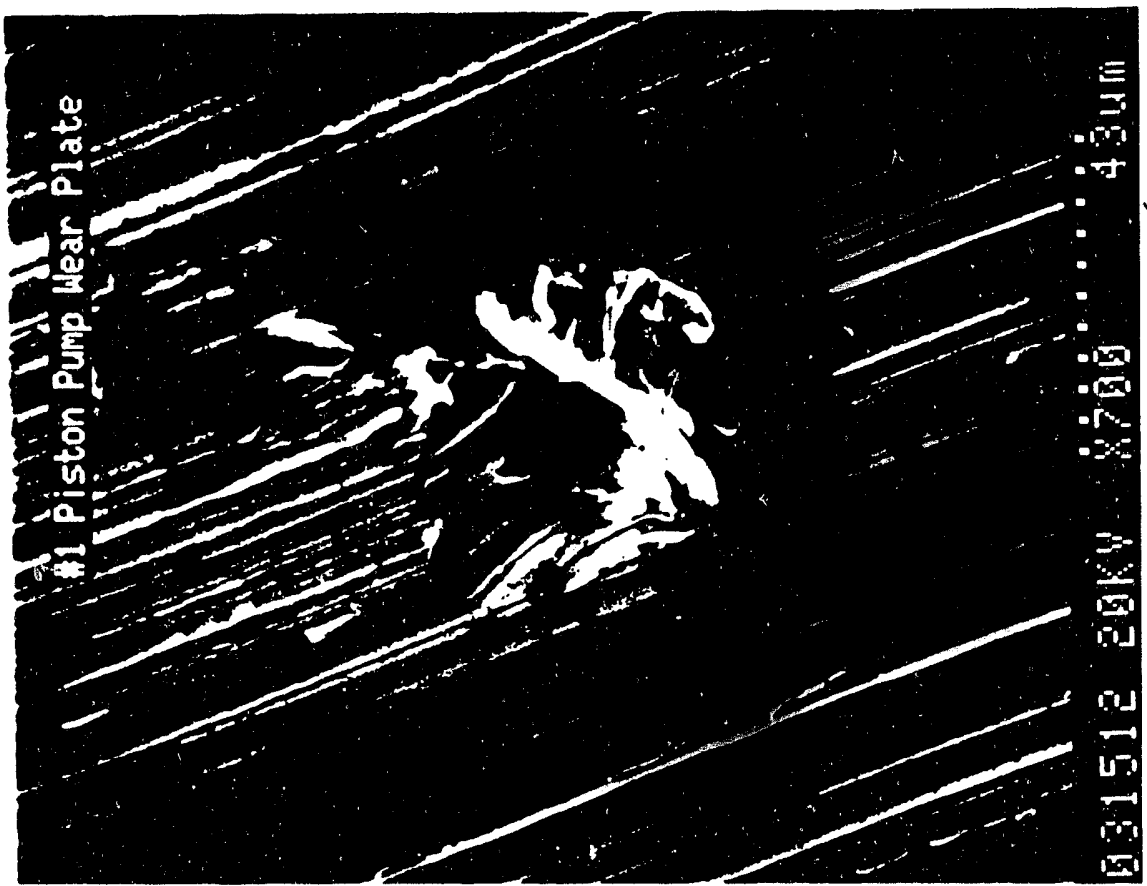

Fig. 2a

SEM photograph of Plate 1 showing a gouge with protruding metal associated with thuse flaws. EDX analysis within the gouge revealed no evidence of foreign material or contamination. 
Gary Sutton

April 6, 1994

SRT-MTS-945052

Page 7 of 19

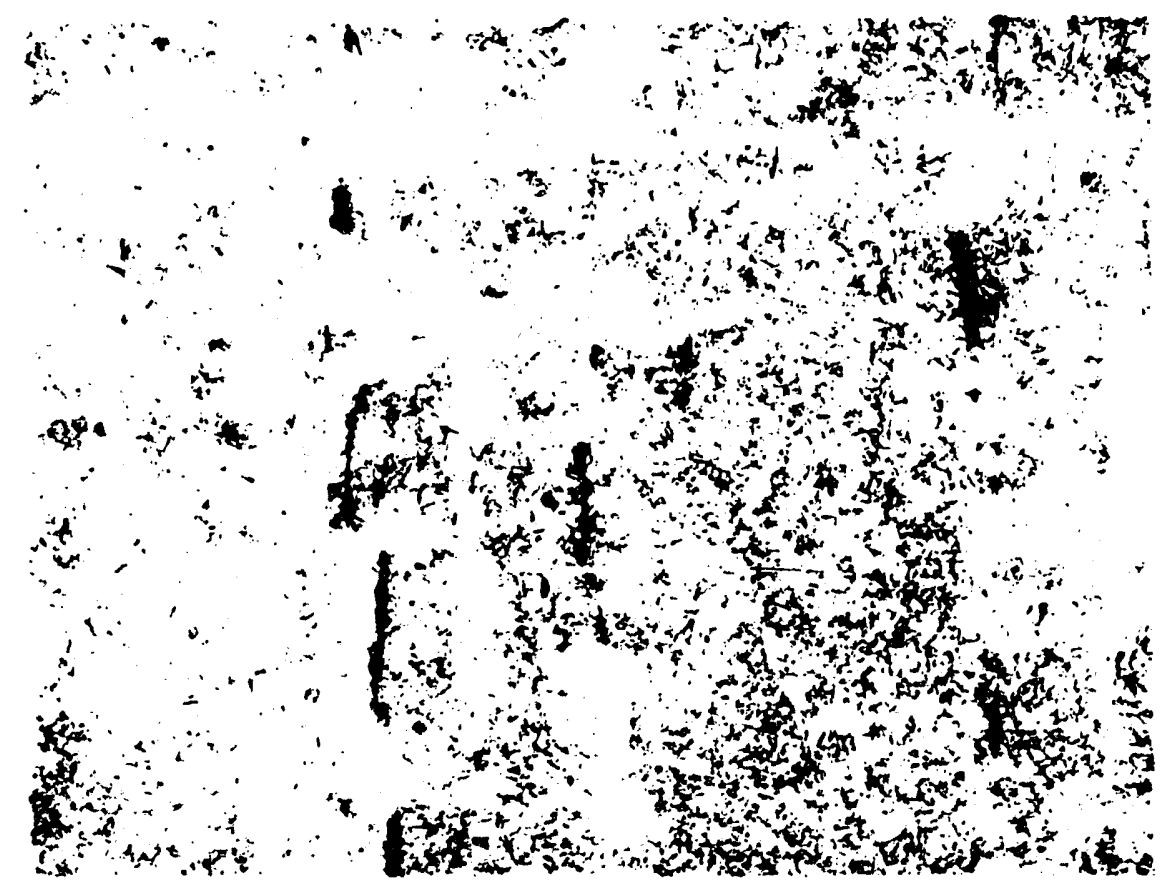

Fig. 3a

Mag. 100X

Etch: $2 \%$ Nital

Photomicrograph showing the microstructure of Plate 1 taken in the cross sectional direction of the plate. The microstructure consists of tempered martensite and the dark elongated phase are non-metallic inclusions.

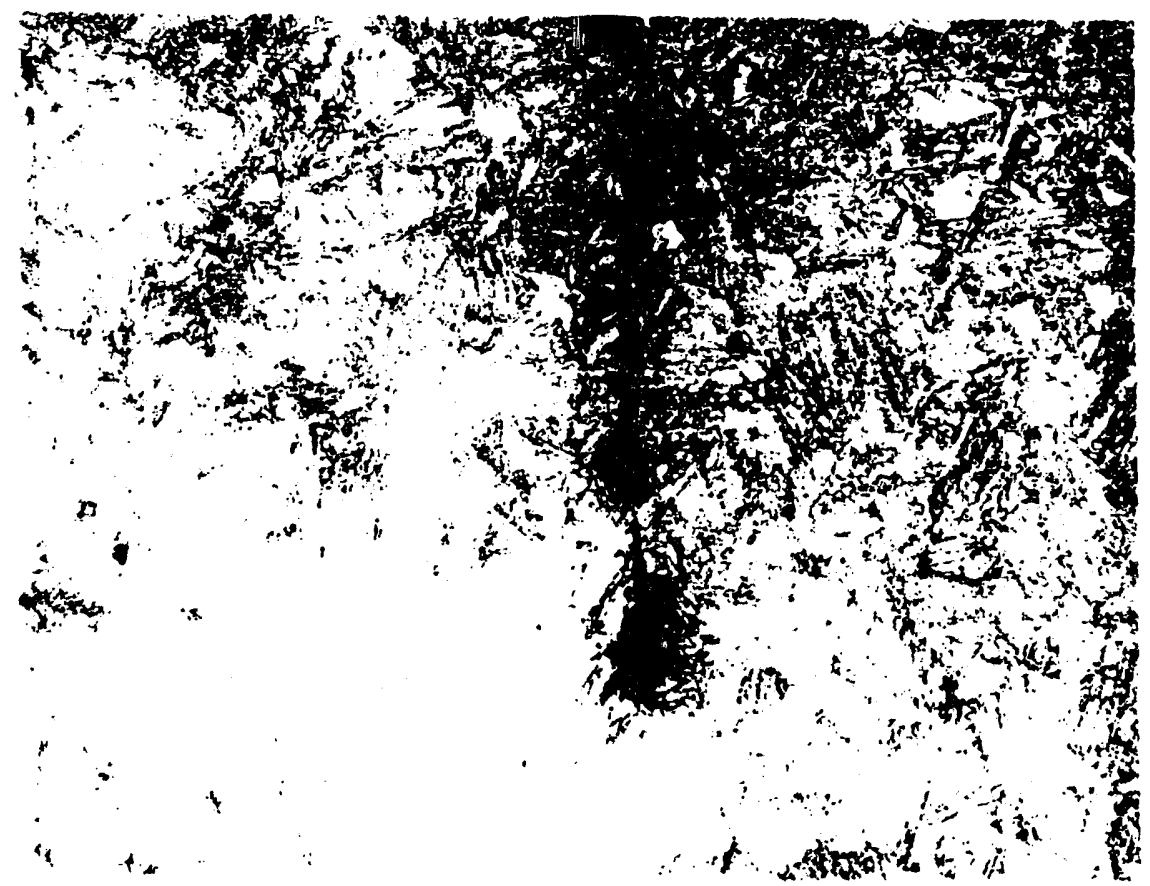

Fig. 3b

Mag. $500 \mathrm{X}$

Etch: $2 \%$ Nital

Photomicrograph shows a higher magnification 
Gary Sutton

April 6, 1994

SRT-MTS-945052

Page 8 of 19

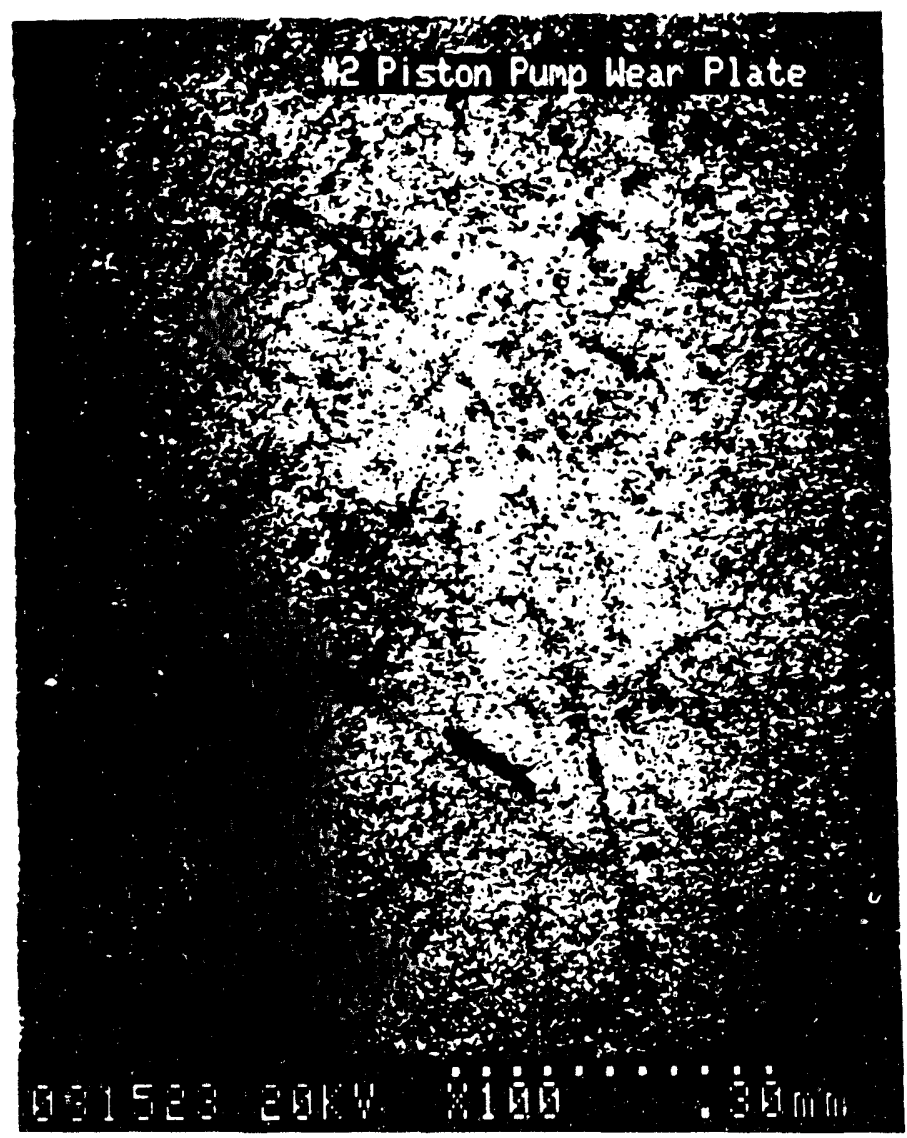

Fig. 4

Mag. 100X

SEM photograph of the working surface of Plate 2 (subjected to a lapping) showing a relatively smoother surface with no evidence (Figure 3 ) of machining marks as observed in plate 1. 
Gary Sutton

April 6, 1994

SRT-MTS-945052

Page 9 of 19

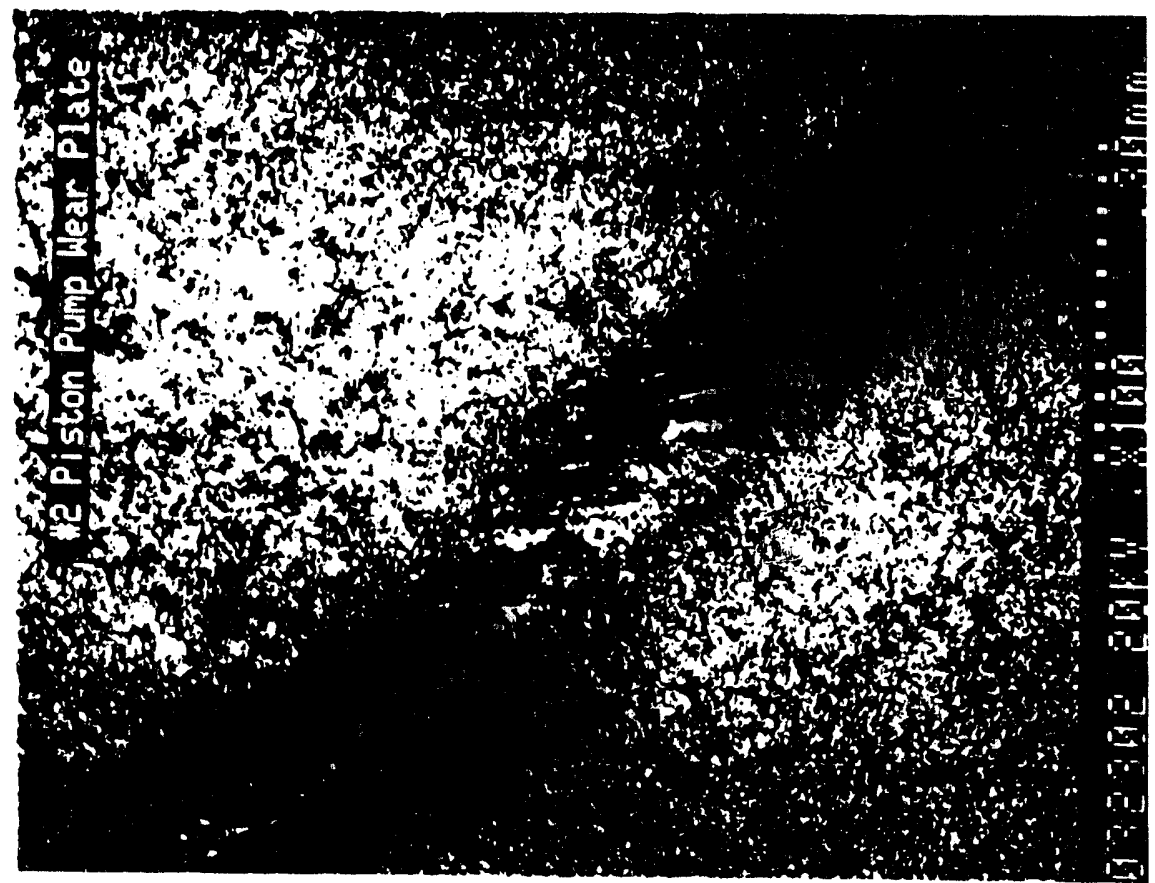

Fig. 5a

Mag. 100X

SEM photograph of Plate 2 showing metal deformation across the surface.

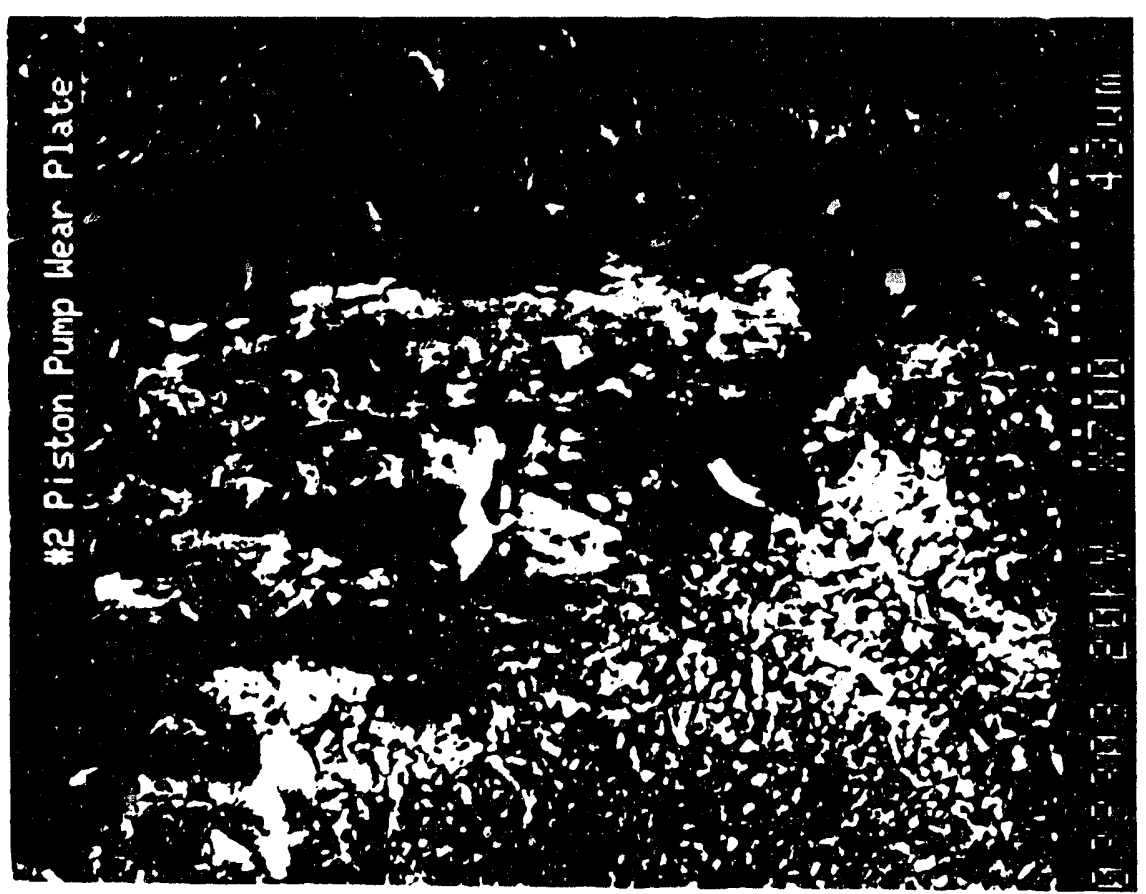

Fig. 5b

A higher magnification of Figure 5a. 
Gary Sutton

April 6, 1994

SRT-MTS-945052

Page 10 of 19

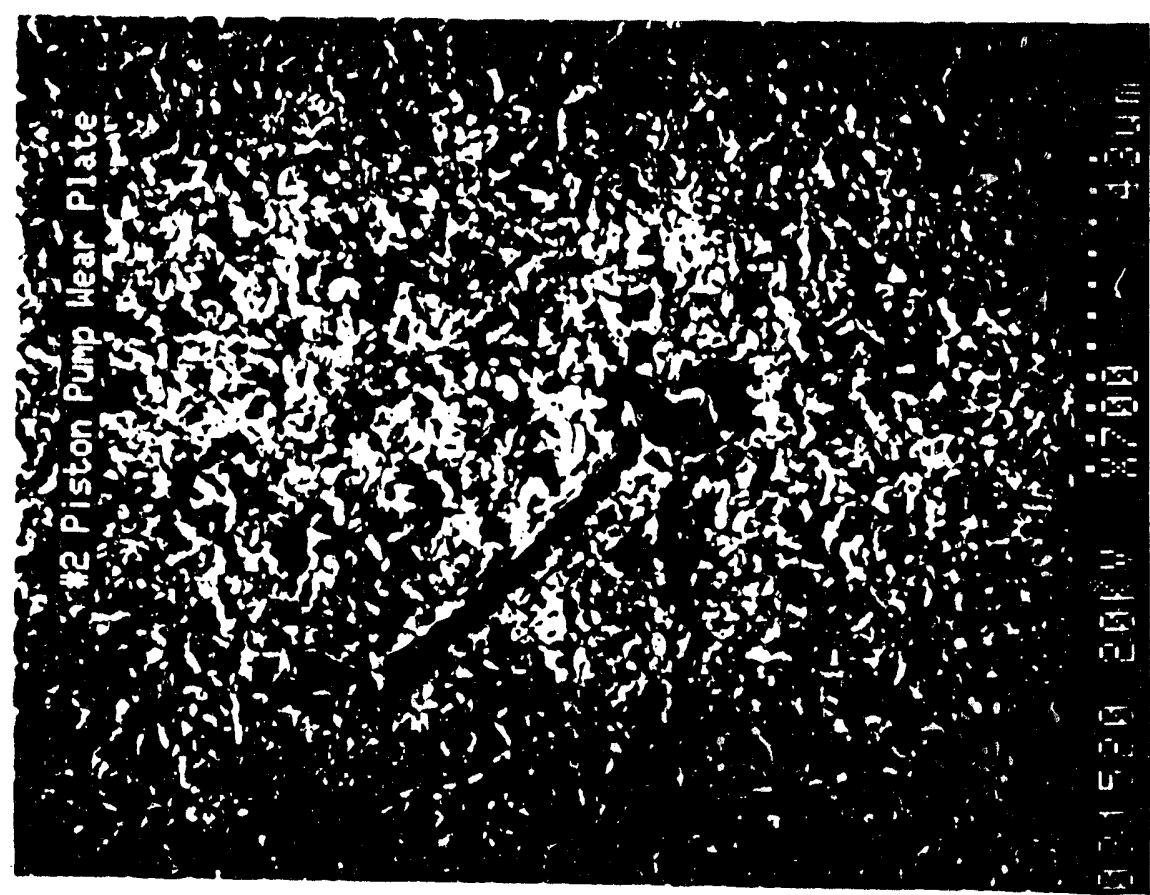

Fig. 6a

Mag. $700 X$

SEM photograph of Plate 2 showing metal deformation across the surface. EDX analysis of the material within the gouge revealed the presence of aluminum.

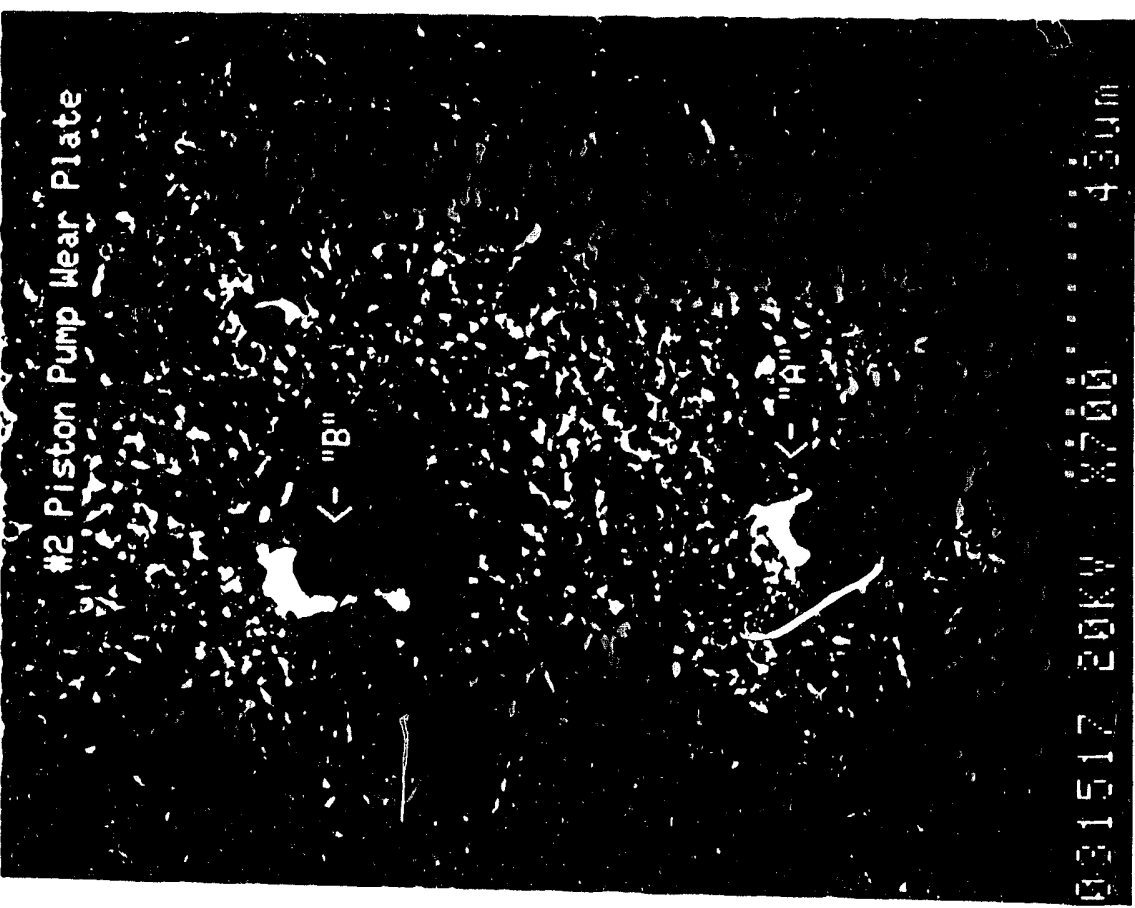

Fig. 6b

Mag. 700X

EDX analysis of the particle (A) was found to contain silicon and particle (B) contained chlorine, potassium, sodium and sulfur. 
Gary Sutton

April 6, 1994

SRT-MTS-945052

Page 11 of 19

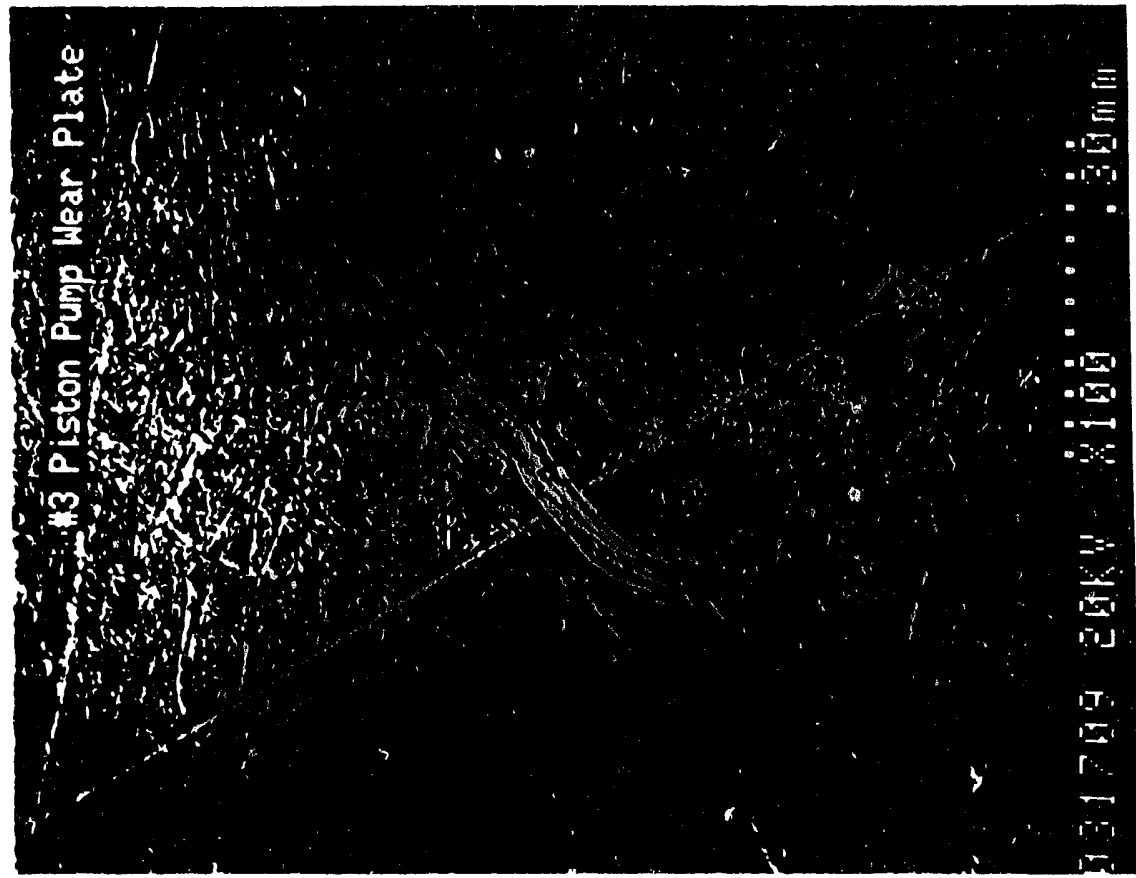

Fig. 7a

Mag. $100 \mathrm{X}$

SEM photograph of the working surface of Plate 3 (vibra slide detergent cleaned) showing a relatively smooth surface similar to that of Plate 2 except for the presence of scratches.

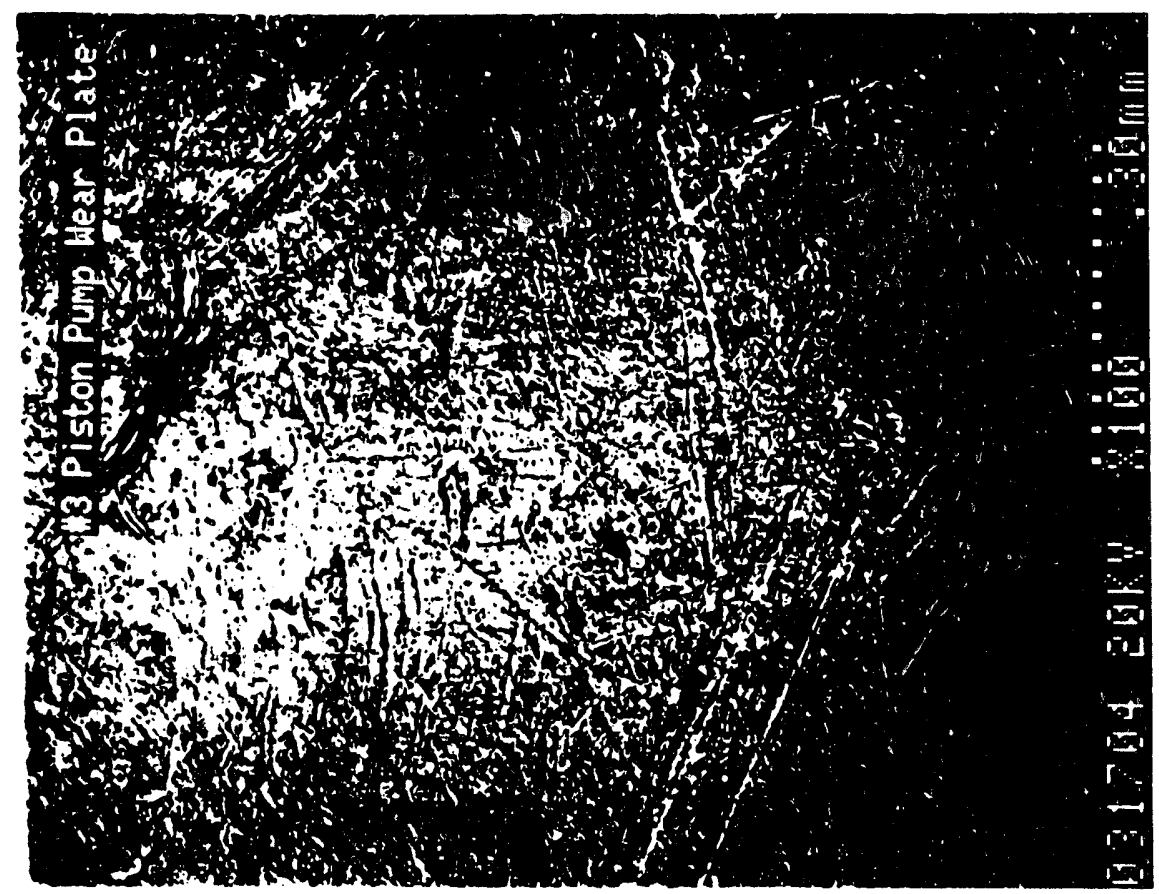

Fig. $7 b$

Another location of Plate 3

Mag. $700 X$ 
Gary Sutton

April 6, 1994

SRT-MTS-945052

Page 12 of 19

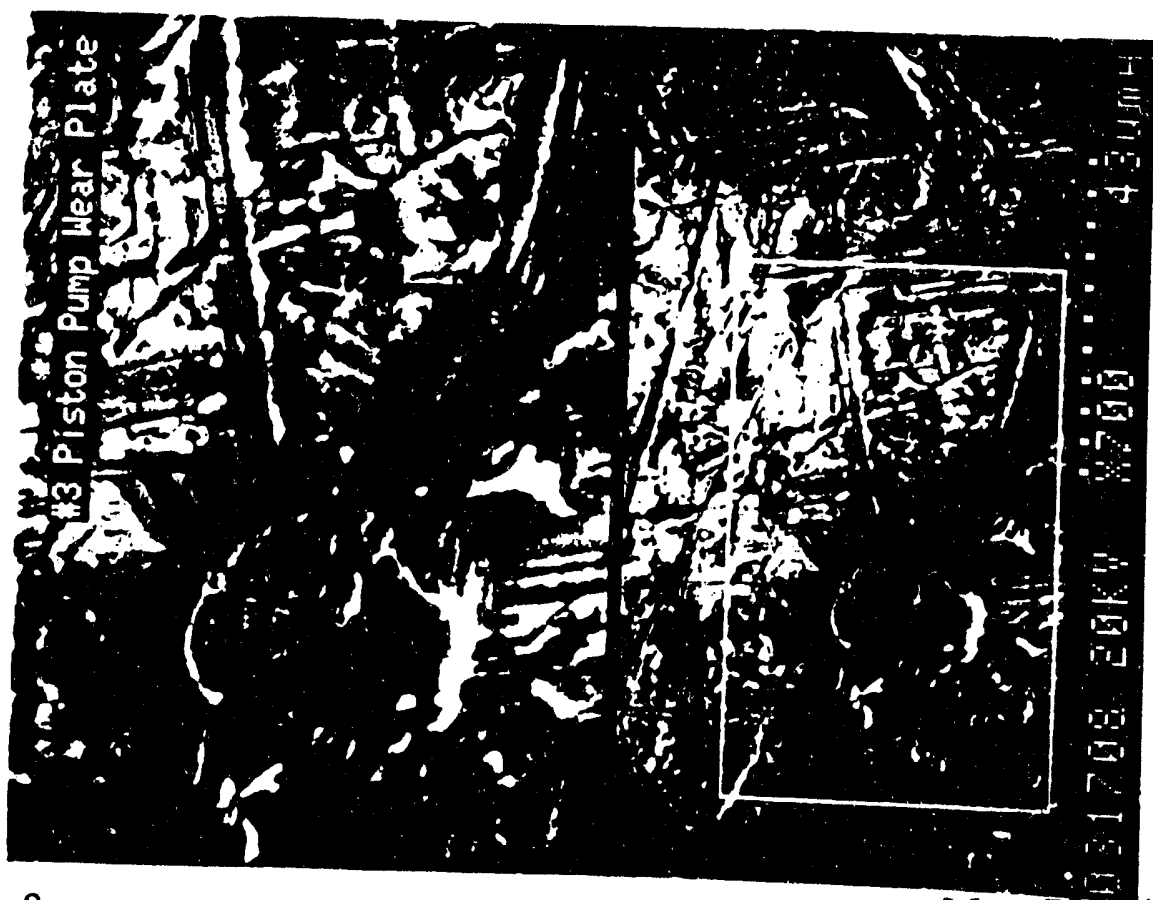

Fig. 8a

Mag. $700 \mathrm{X} / 1400 \mathrm{X}$

SEM photograph of Plate 3 showing scratches and a gouge with excess metal seen around the gouge. This excess metal appears to have been flatten presumably during the cleaning operation indicating the gouge existed prior to the cleaning operation. EDX analysis of the material within the gouge was found to be aluminum.

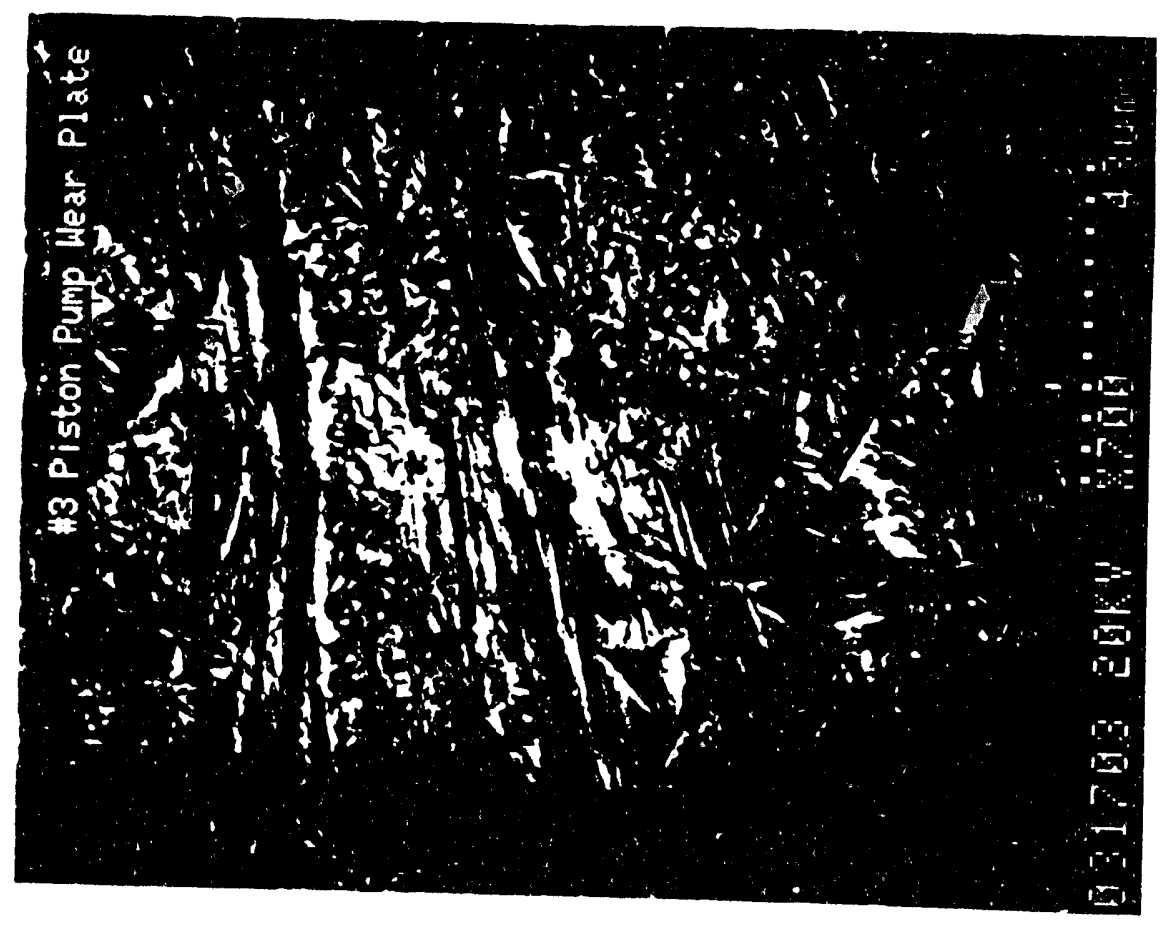

Fig. $8 \mathrm{~b}$ Mag. 700X

A second SEM photograph of Plate 3 showing scratches and a gouges 
Gary Sutton

April 6, 1994

SRT-MTS-945052

Page 13 of 19

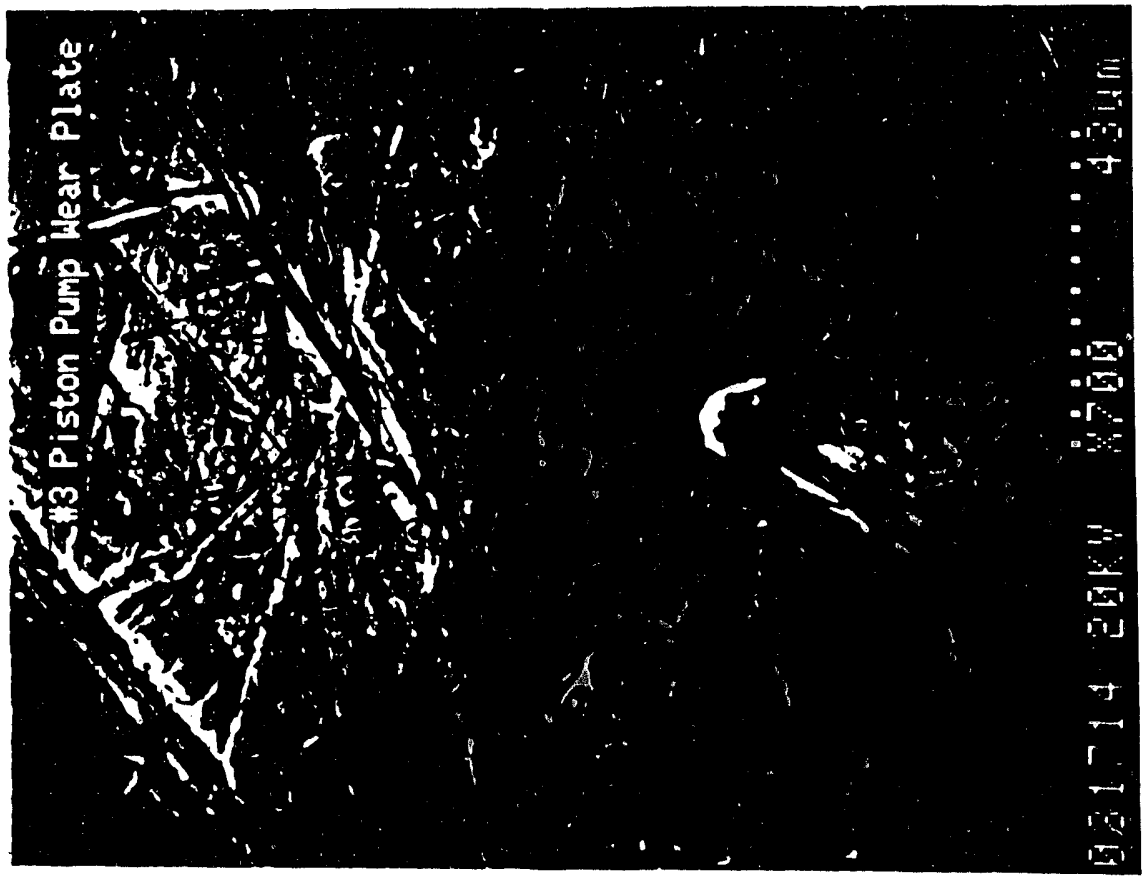

Fig. 9a

Mag. $700 X$

SEM photograph of Plate 3 showing scratches and a gouge with excess metal seen around the gouge. This loose metal appears to be undisturbed, suggesting the damage was induce during the cleaning operation. EDX analysis the material within the gouge found no evidence of foreign material.

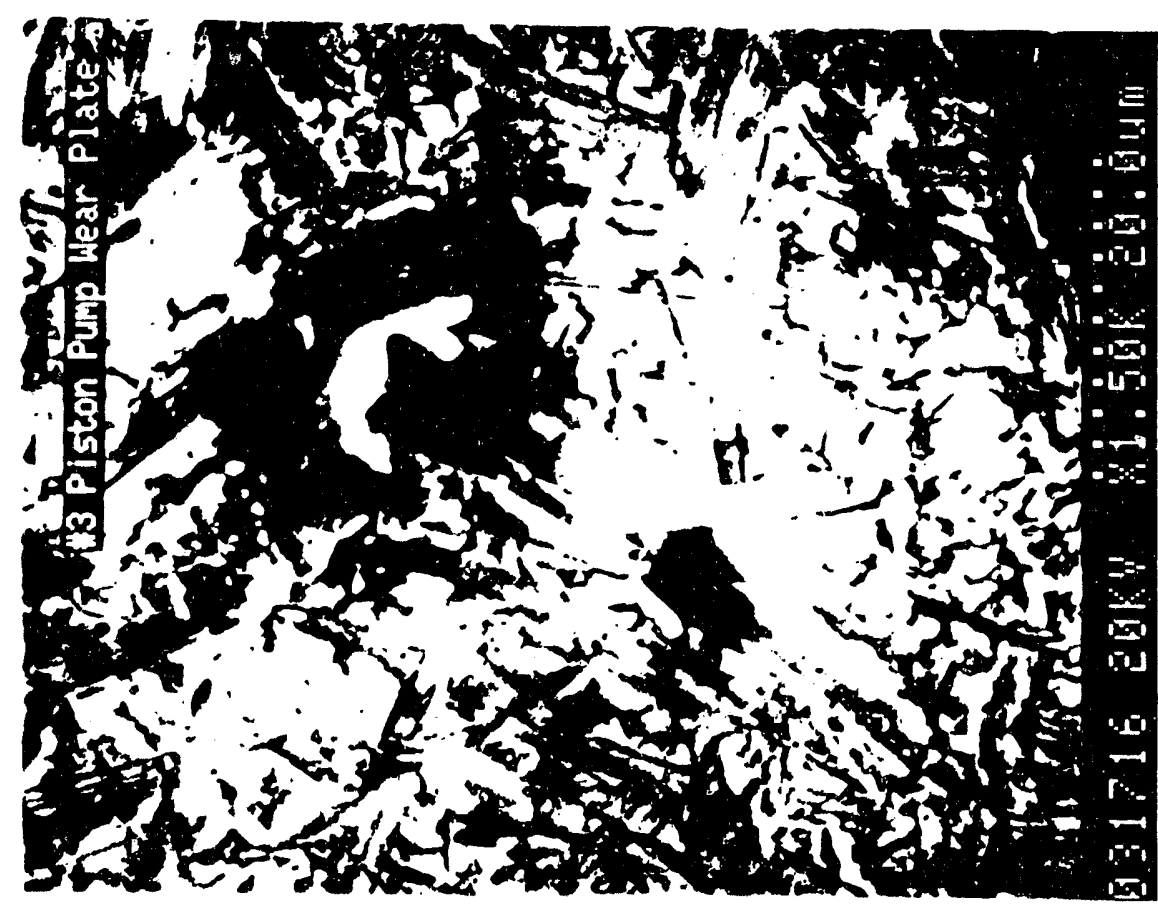

Fig. 9b

Higher magnification of Figure 9a.

Mag. 1500X 
Gary Sutton

April 6, 1994

SRT-MTS-945052

Page 14 of 19

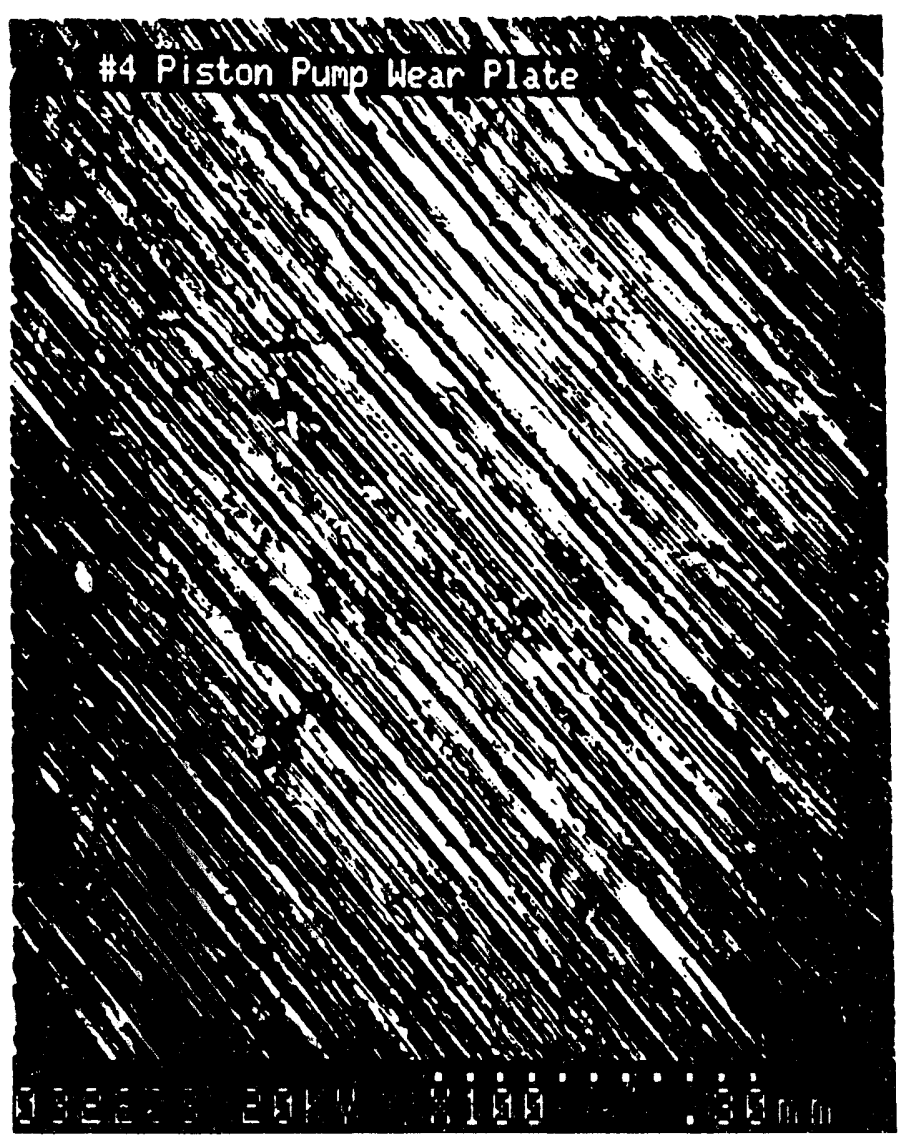

Fig. 10

Mag. $100 \mathrm{X}$ SEM photograph of the working surface of Plate 4 (subjected to muriatic acid etching) displaying machining marks over the entire surface and is very similar to that of plate 1 (Figure 1 ). 
Gary Sutton

April 6, 1994

SRT-MTS-945052

Page 15 of 19

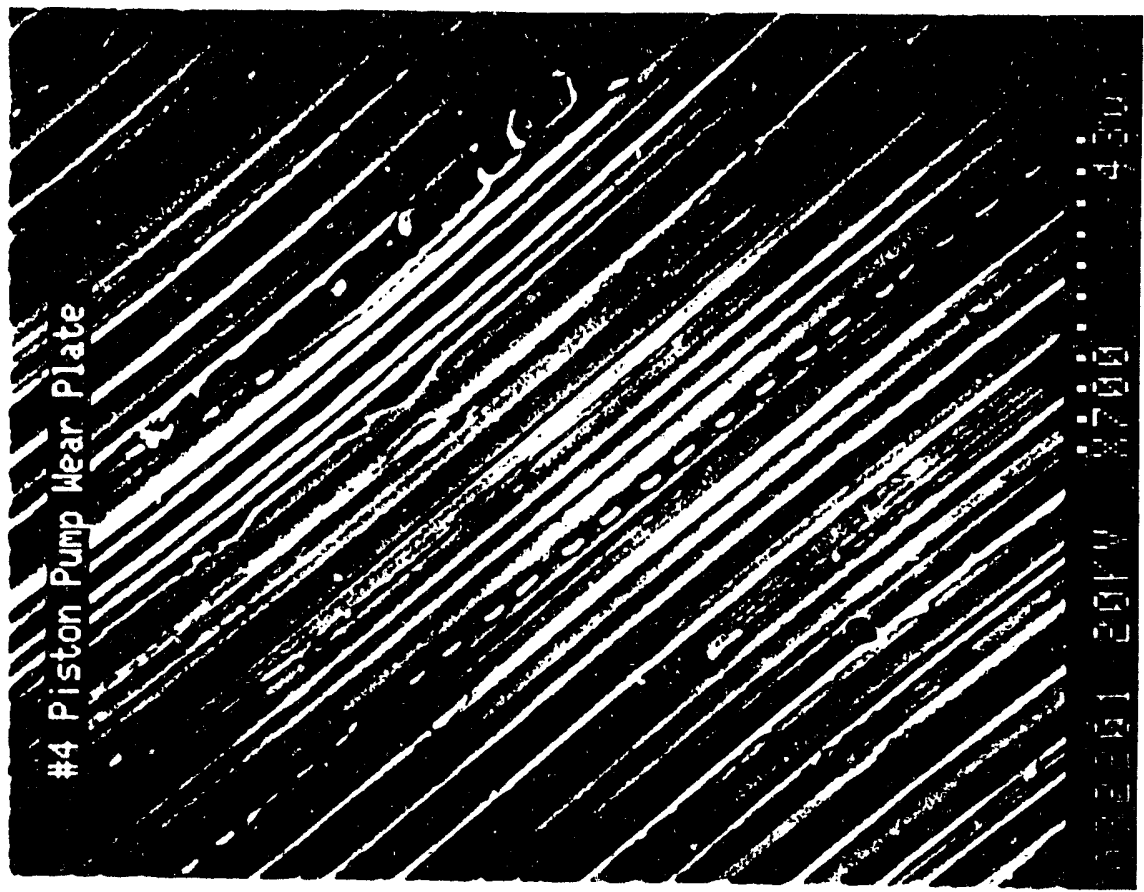

Fig. 11a

Mag. $700 X$

SEM photograph of Plate 4 showing the presence of iron particles (confirmed by EDX analysis) and appear to be associated with the machining of the part.

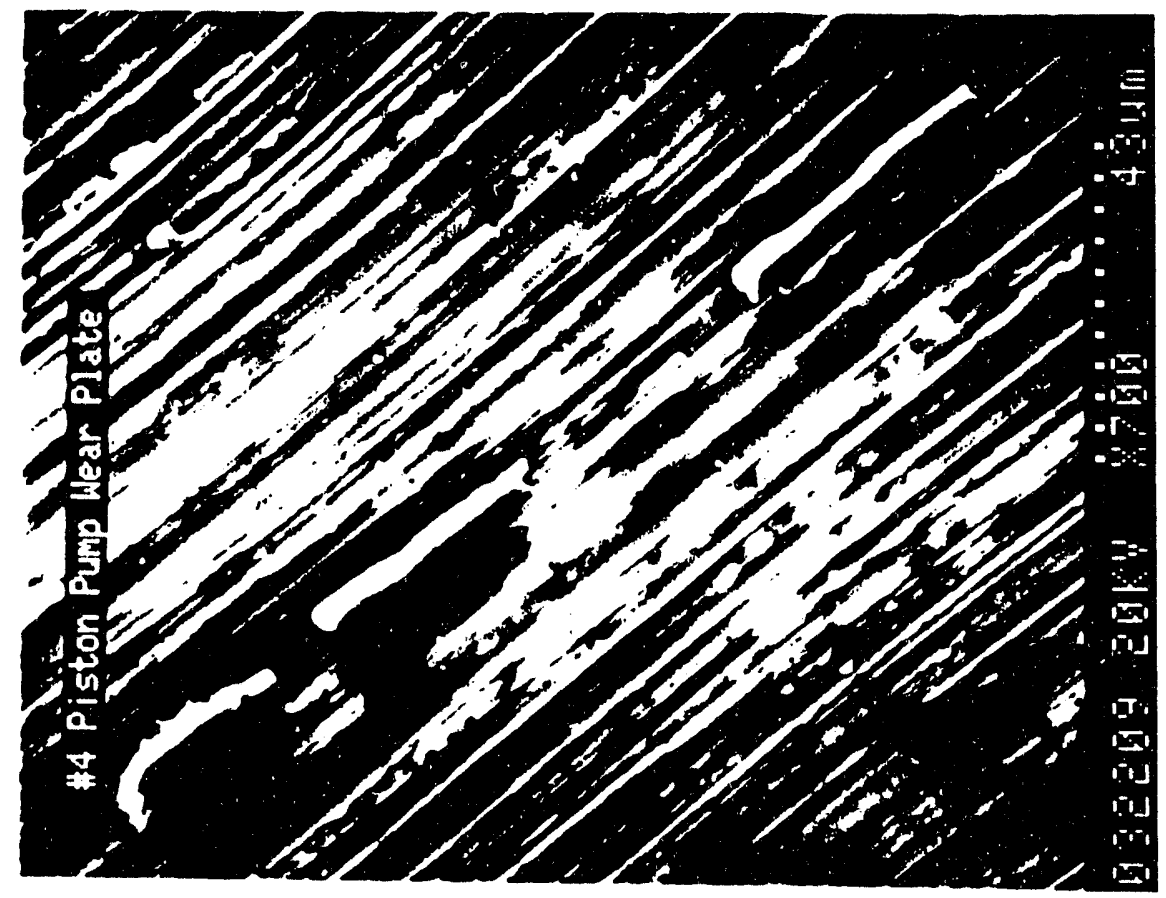

Fig. $11 b$

Same as Figure lla but at another location.

Mag. 1500X 
Gary Sutton

April 6, 1994

SRT-MTS-945052

Page 16 of 19

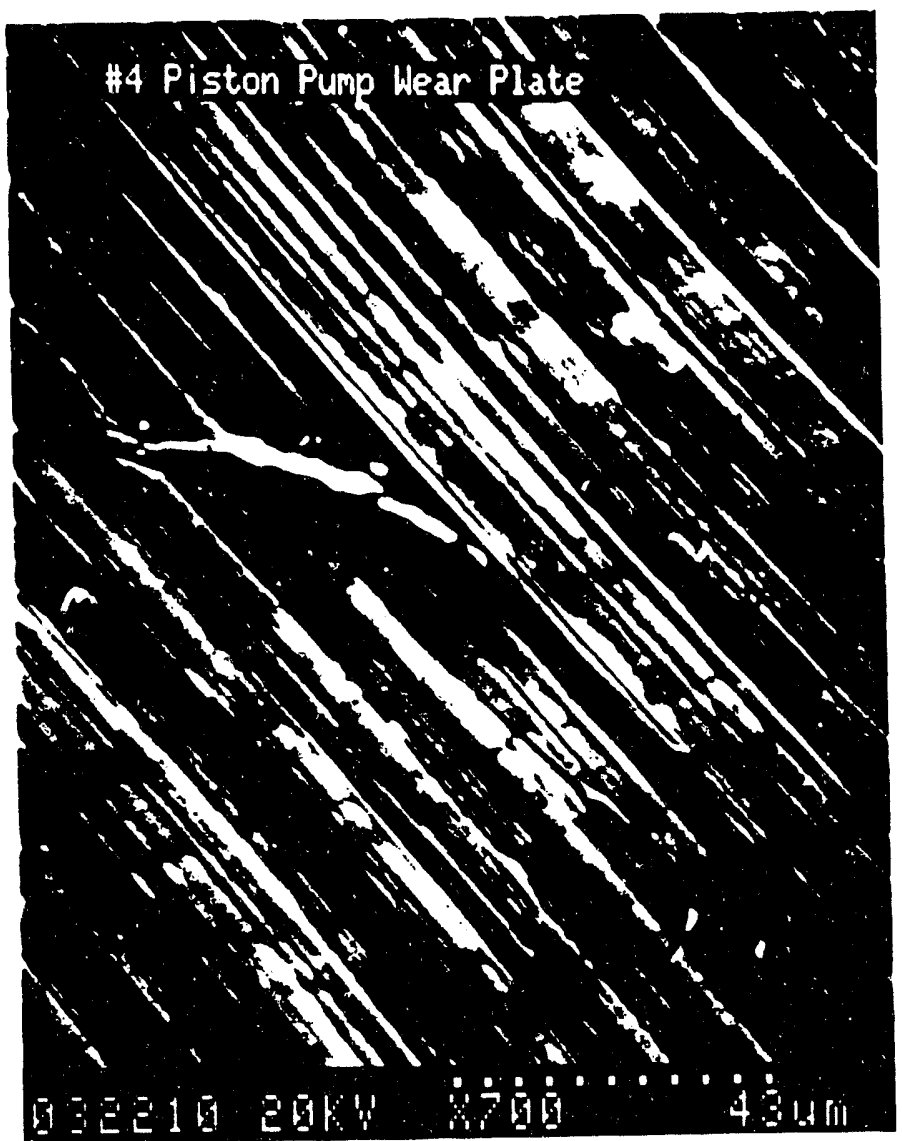

Fig. 12

Mag. 700X SEM photograph of Plate 4 showing a gouges. EDX analysis within the gouges revealed no evidence of foreign material or contamination. 
Gary Sutton

April 6, 1994

SRT-MTS-945052

Page 17 of 19

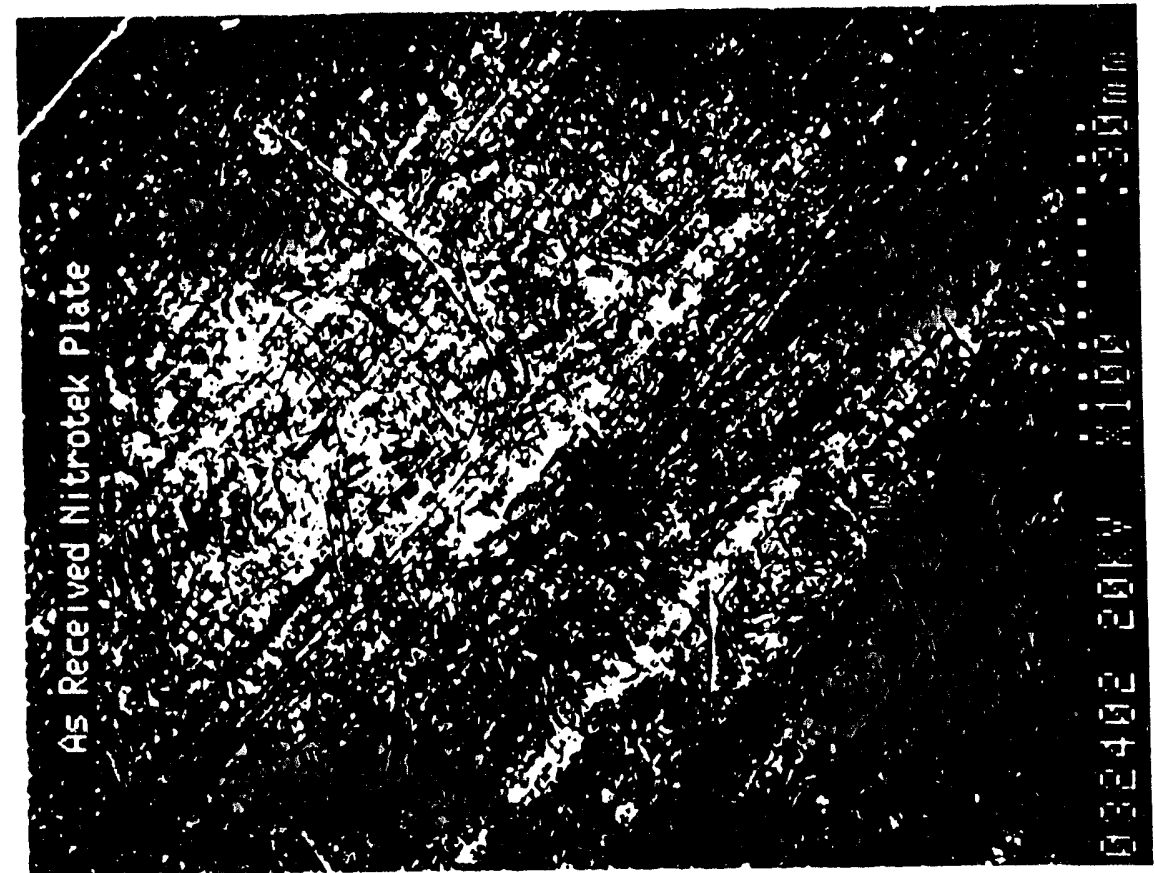

Fig. 13a

Mag. 100X

SEM photograph of the working surface of Plate 5 (nitrotec surface hardened) was relatively smooth with scratches. This surface was very similar to that of plate 3 .

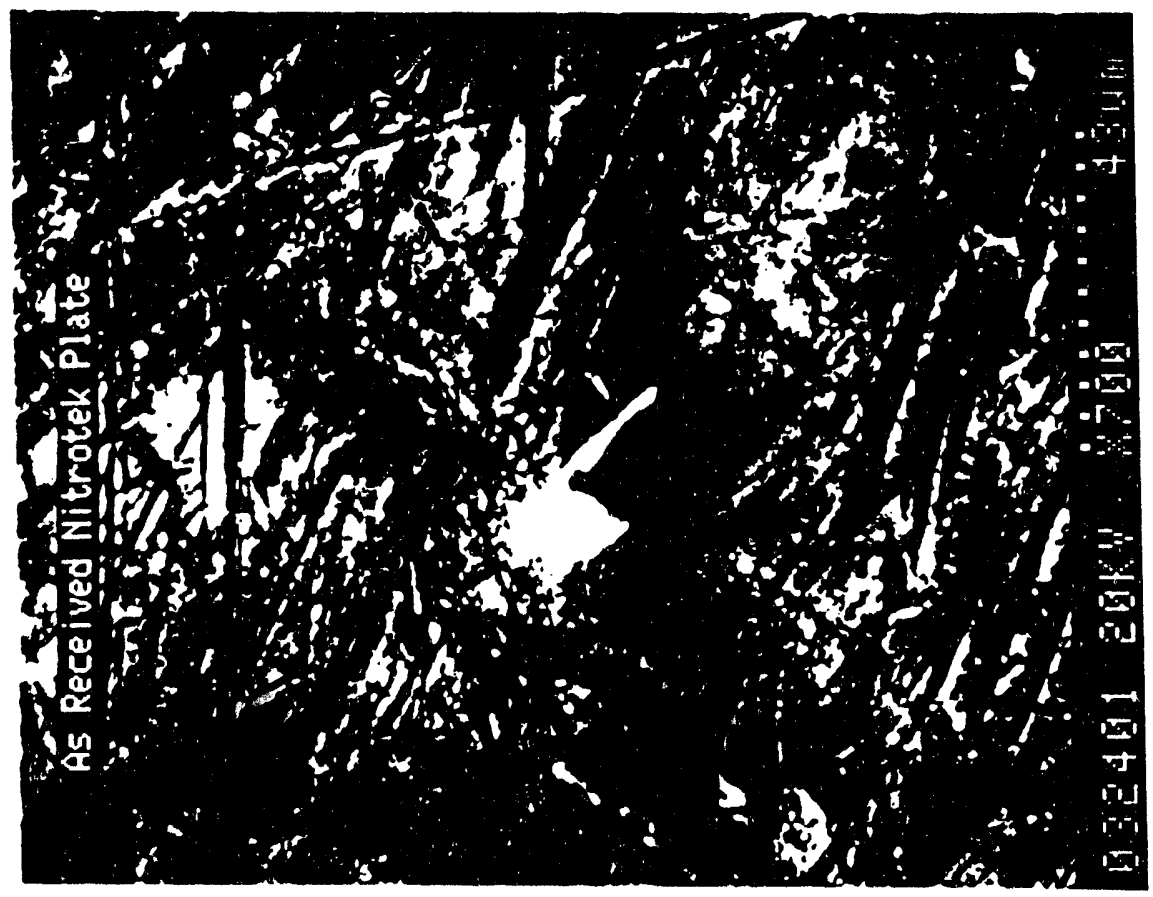

Fig. $13 b$ Mag. 700X SEM photograph showing a chlorine containing particle on the surface. 
Gary Sutton

April 6, 1994

SRT-MTS-945052

Page 18 of 19

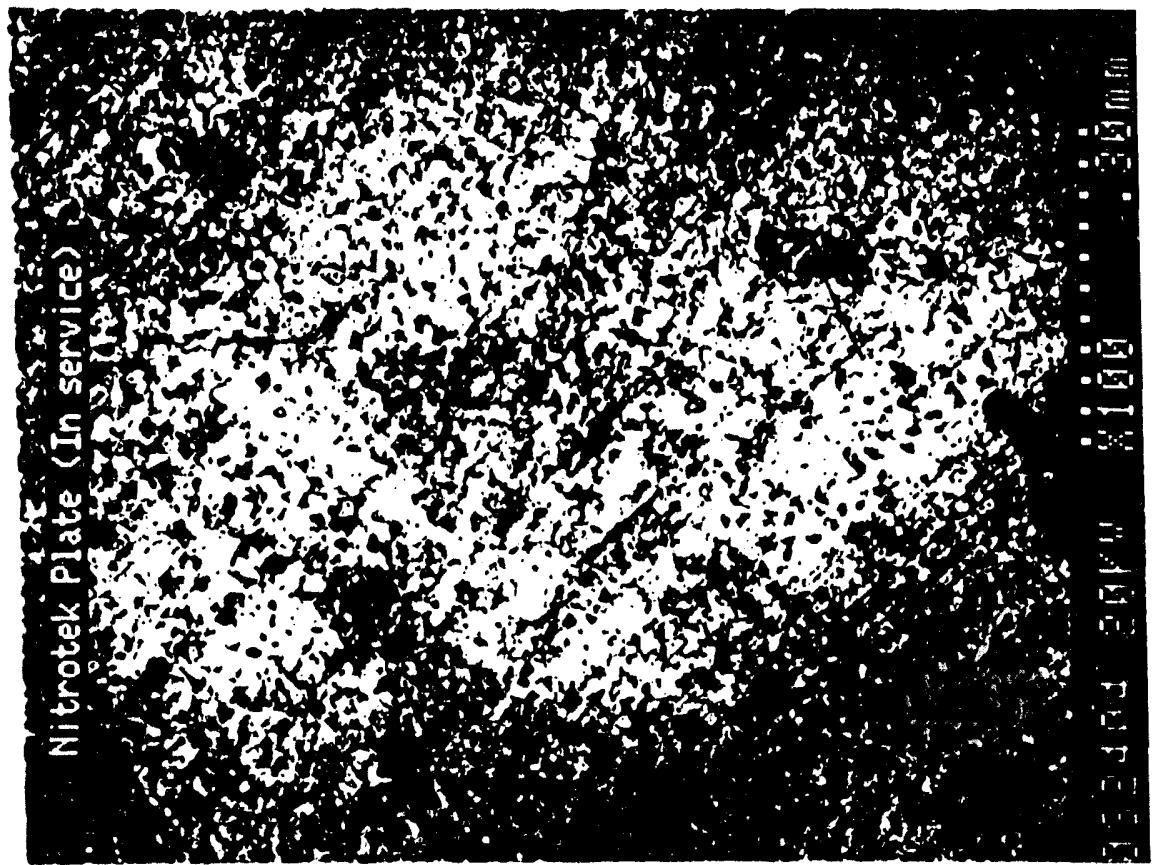

Fig. 14a

Mag. $100 \mathrm{X}$

SEM photograph of Plate 6 ("Nitrotec" surface hardened, performance tested) showing surface oxidation and what appears to be faint machining marks.

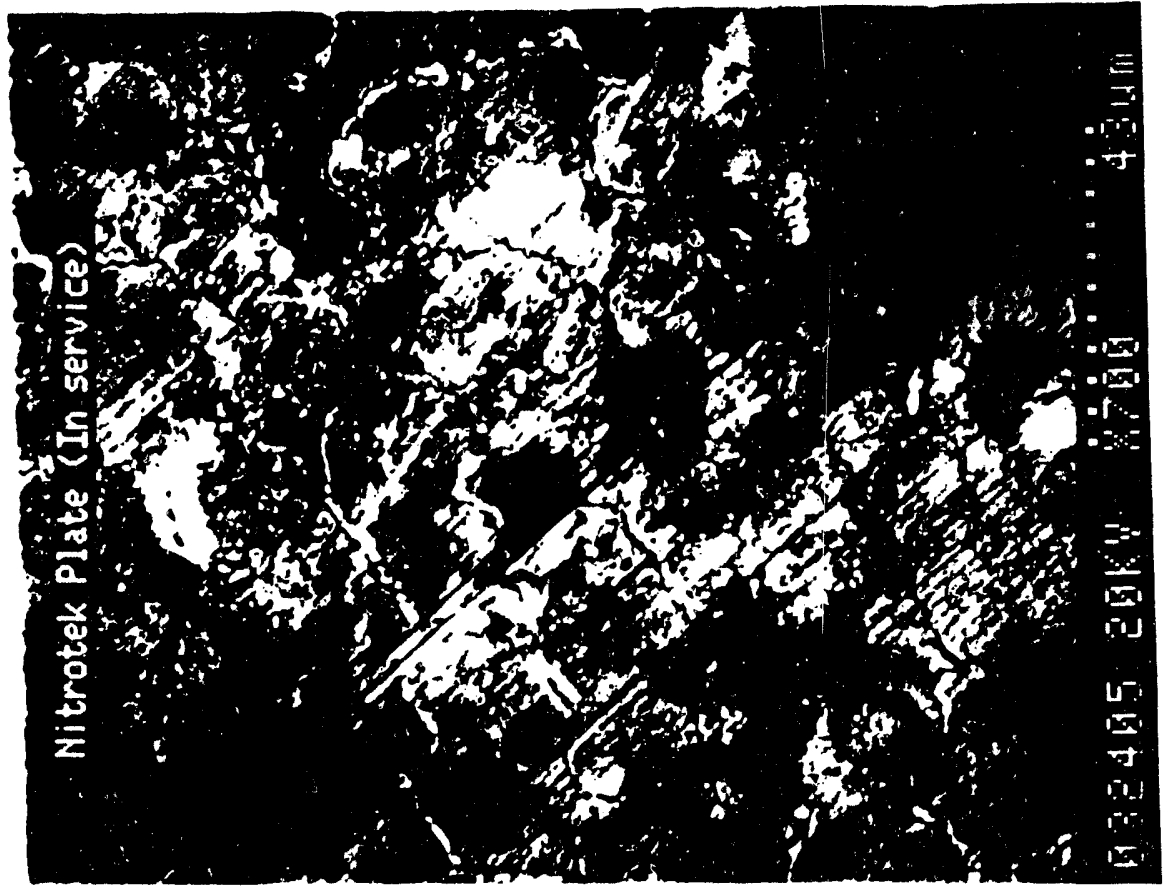

Fig. 14b

Mag. 700X

Higher magnification showing oxidation. 
Gary Sutton

April 6, 1994

SRT-MTS-945052

Page 19 of 19

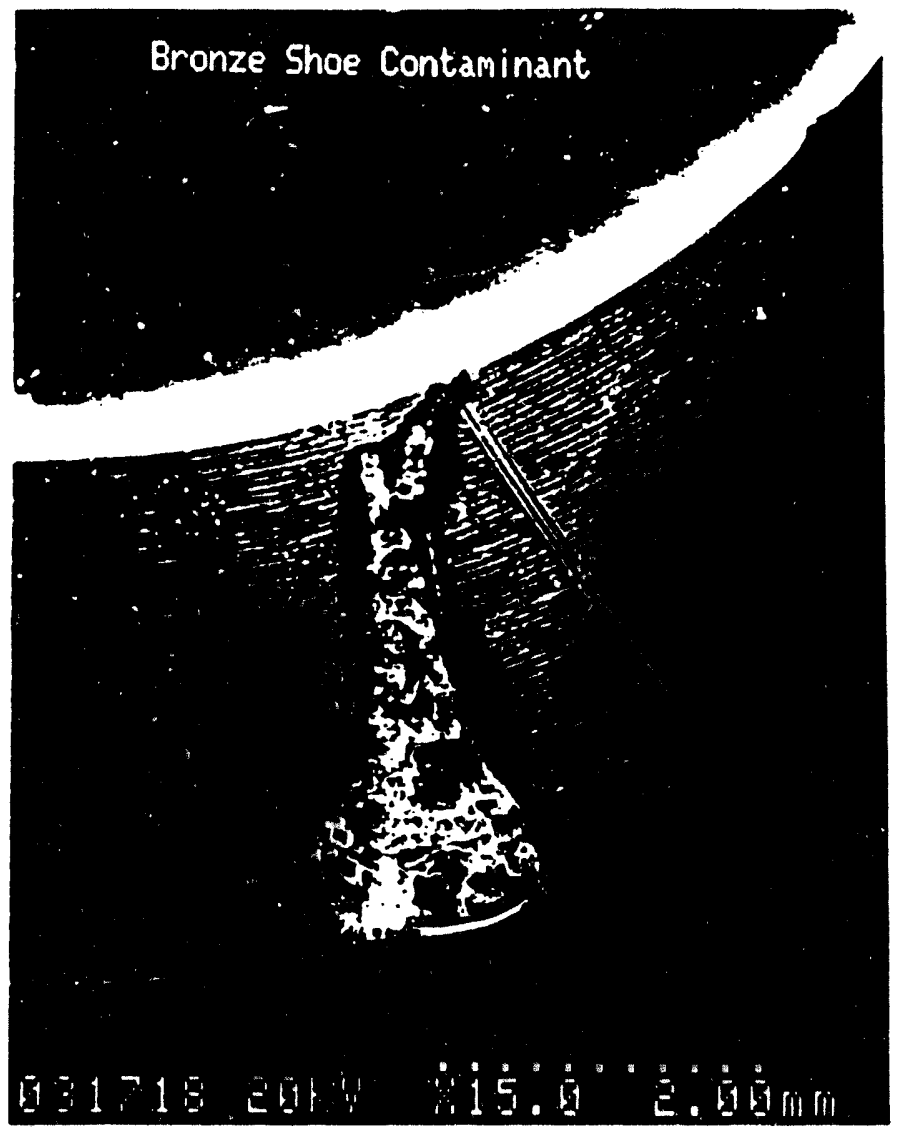

Fig. 15

Mag. 15X

SEM photograph shows the surface contaminant on the brass shoe. The EDX analysis indicated the contaminant was essentially iron. 

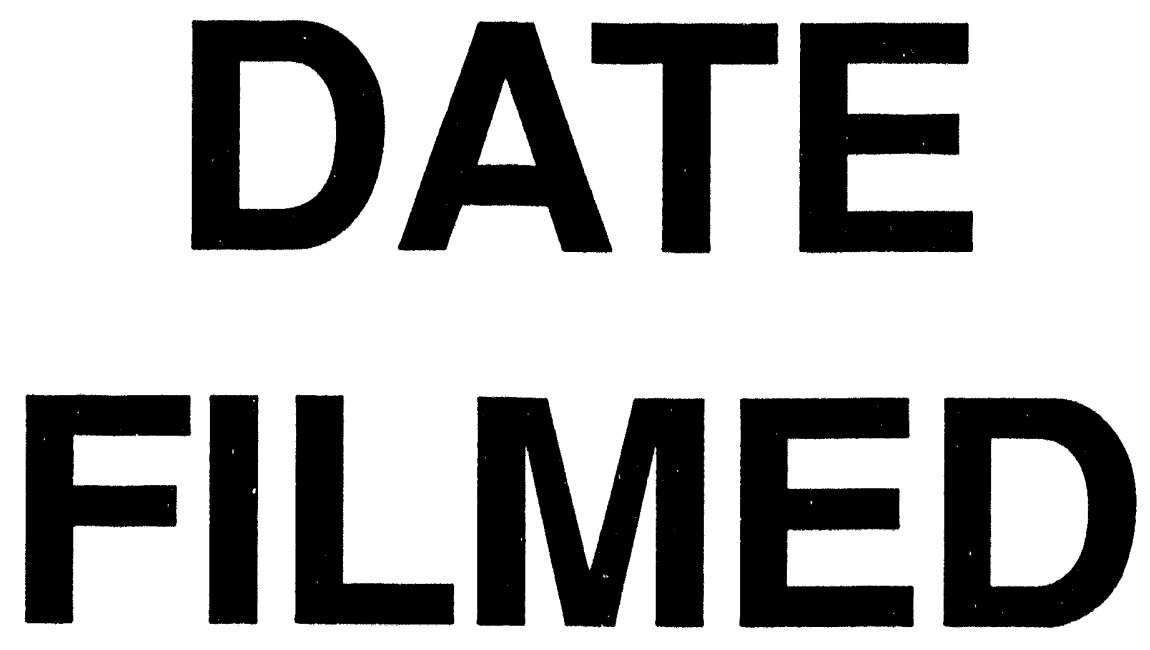

$6 / / 6 / 94$
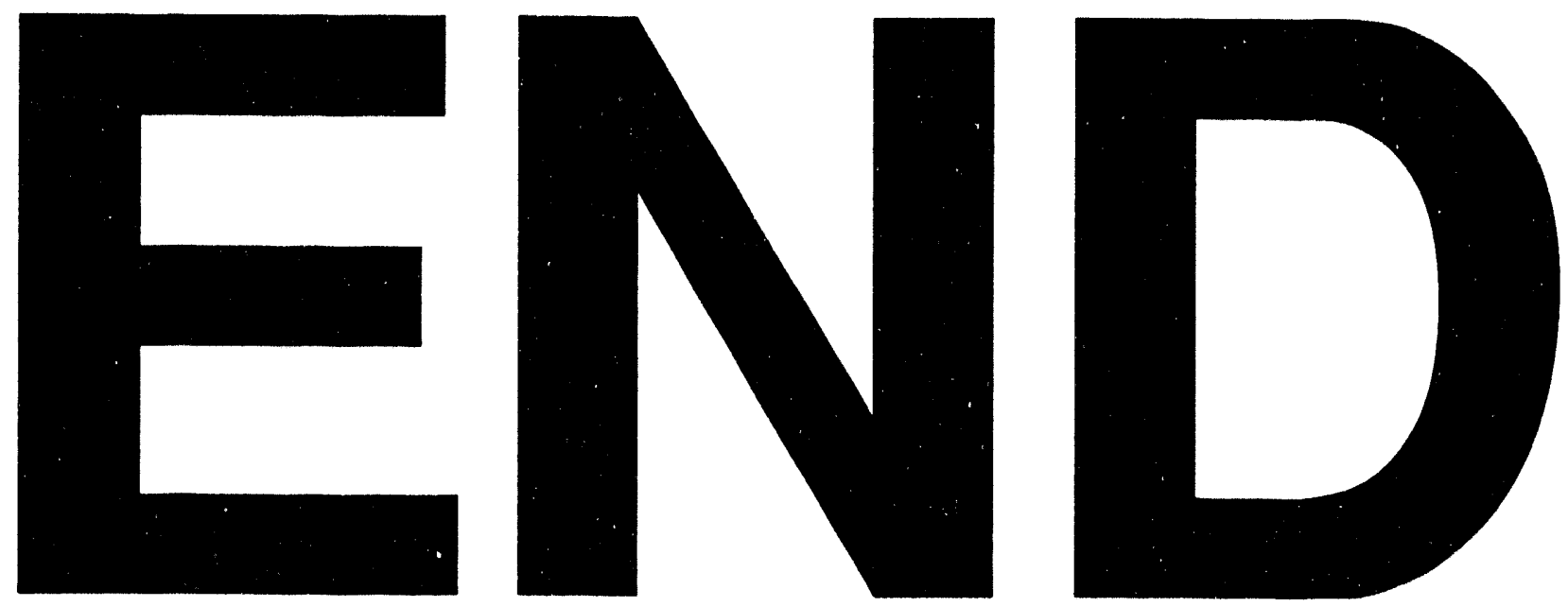
